MARLENE APARECIDA FERREIRA PINTO

\title{
ESTUDO DA EXPRESSÃO GÊNICA E PROTEICA \\ DO FATOR DE TRANSCRIÇÃO AP-1 EM \\ CULTURAS DE CÉLULAS DE TUMORES \\ ADRENOCORTICAIS
}

Dissertação de Mestrado apresentada ao
Programa de Pós-Graduação em Ciências
Morfofuncionais do Instituto de Ciências
Biomédicas da Universidade de São Paulo, para
obtenção do título de mestre em Ciências
Morfofuncionais.

SÃO PAULO

2014 


\title{
MARLENE APARECIDA FERREIRA PINTO
}

\author{
ESTUDO DA EXPRESSÃO GÊNICA E \\ PROTEICA DO FATOR DE TRANSCRIÇÃO \\ AP-1 EM CULTURAS DE CÉLULAS DE \\ TUMORES ADRENOCORTICAIS
}

\begin{abstract}
Dissertação de Mestrado apresentada ao Programa de Pós-Graduação em Ciências Morfofuncionais do Instituto de Ciências Biomédicas da Universidade de São Paulo, para obtenção do título de mestre em Ciências Morfofuncionais.

Área de Concentração: Ciências Morfofuncionais

Orientadora: Profa. Dra. Claudimara Ferini Pacicco Lotfi.
\end{abstract}

Versão Original

SÃO PAULO

2014 


\section{DADOS DE CATALOGAÇÃO NA PUBLICAÇÃO (CIP)}

Serviço de Biblioteca e Informaçăo Biomédica do Instituto de Ciências Biomédicas da Universidade de São Paulo

reproduçằo nằ autorizada pelo autor

Pinto, Marlene Aparecida Ferreira.

Estudo da expressão gênica e proteica do fator de transcrição ap-1 em culturas de células de tumores adrenocorticais / Marlene Aparecida Ferreira Pinto. -- São Paulo, 2014.

Orientador: Profa. Dra. Claudimara Ferini Pacicco Lofti.

Dissertação (Mestrado) - Universidade de São Paulo. Instituto de Ciências Biomédicas. Departamento de Anatomia. Área de concentração: Ciências Morfofuncionais. Linha de pesquisa: Estudo da sinalização e expressão gênica na proliferação de células normais e tumorais da suprarrenal.

Versão do título para o inglês: Analysis of JUN and FOS gene expression in adult and pediatric adrenocortical tumor cells.

1. Tumores adrenocorticais 2. AP-1 3. Genes JUN e FOS 4. Cultura de células 5. Ciclo celular 6. Expressāo gênica I. Lofti, Profa. Dra. Claudimara Ferini Pacicco II. Universidade de São Paulo. Instituto de Ciências Biomédicas. Programa de Pós-Graduação em Ciências Morfofuncionais III. Titulo. 
Candidato(a): $\quad$ Marlene Aparecida Ferreira Pinto.

Título da Dissertação: Estudo da expressão gênica e proteica do fator de transcrição AP-1 em culturas de células de tumores adrenocorticais.

Orientador(a): $\quad$ Profa. Dra. Claudimara Ferini Pacicco Lofti.

A Comissão Julgadora dos trabalhos de Defesa da Dissertação de Mestrado, em sessão pública realizada a ........................... considerou
( ) Aprovado(a)
( ) Reprovado(a)

Examinador(a): Assinatura:

Nome:

Instituição:

Examinador(a): Assinatura:

Nome:

Instituição:

Presidente: Assinatura:

Nome:

Instituição: 
São Paulo, 14 de junho de 2012.

\section{PARECER 1053/CEP}

A Comissāo de Ética em Pesquisas em Seres Humanos do ICB, na sessāo realizada no dia 13.06.2012. APROvou o projeto intitulado: "Estudo da expressão gênica e protéica do fator de franscriçào AP-l em cultura de céluias de tumores adrenocorticais" dos autores Profa. Dra. Claudimara FerrinI Pacicco Lofil e g aluna Marlene Aparecida Ferreira Pinto.

Informa ainda, que seu projeto será regularizado junto a Plataforma Brasil. assim que a CONEP iberar a acesso ao sistema.

Cabe aos Pesquisadores executantes elaborar e apresentar a este Comitê, relatórios anuais (parciais ou final), de acordo com a resoluçâo 196/06 do Conselho Nacional da Saúde, item IX. 2 letra c.

O primeiro relatório deverá ser encaminhado à Secretaria deste CEP em 13.06.2013.

Atenciosamente,

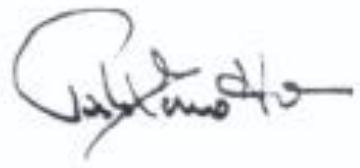

Prof. Dr. PAOLOM.A.ZANOTO

Coordenador da Comissão de Ética em

Pesquisas com Seres Humanos - ICB/USP

Comissào de Ética em Pesquisa com Seres Humanos do instituto de Ciéncias Biomedicas / USP Aprovada pela Comissăo Nacional de Etica em Pesquisa - CONEP, em 10 de feverairo de 1998. 
Aos meus pais, Edison e Fátima.

Ao meu irmão Raphael e ao meu namorado Ricardo. 


\section{AGRADECIMENTOS}

À Deus e a Nossa Senhora Aparecida;

Aos meus pais, Edison e Fátima meus exemplos de garra e determinação, pelo incentivo, pela cumplicidade e amor incondicional;

Ao meu irmão Raphael que aos 15 anos percebeu a importância desse trabalho e me apoiou com sua amizade e companheirismo;

Ao meu namorado Ricardo por estar ao meu lado e transmitir a calma e a serenidade necessárias para conclusão desse trabalho, por sua paciência, companheirismo e amor;

À família Ferreira pelos momentos de descontração, especialmente à minha madrinha Sandra por seu carinho;

À minha tia Rosana pelas palavras de incentivo;

Às minhas amigas Carolina, Danielle, Larissa e Thayane pela amizade;

À minha orientadora Claudimara Lotfi, pela oportunidade e pelo apoio;

Aos colegas do laboratório de Estrutura e Função Celular pelo apoio técnico e convívio diário, especialmente à Amanda Teixeira Rodrigues que se tornou uma amiga para todas as horas;

Aos inúmeros colegas que passaram pelo laboratório, à Gabrielle Ebling Mattos por todo ensinamento, Eduardo Teodoro, Rafael Buoro, Natália Nosé, Paulo Roberto, Talita Vrechi e Érika Fernandes pelo apoio.

Aos funcionários do Departamento de Anatomia, do Instituto de Ciências Biomédicas- ICB3, principalmente à técnica Amanda Ribeiro de Oliveira.

Aos componentes da minha banca de qualificação: Dra.Camila Dale, Dra.Nathalie Cella, Dr.Antonio Lerário, pelos valiosos comentários;

À Fapesp pelo investimento; 


\section{RESUMO}

Ferreira M. Estudo da expressão gênica e proteica do fator de transcrição AP-1 em culturas de células de tumores adrenocorticais. [dissertação (Mestrado em Ciências Morfofuncionais)]. São Paulo: Instituto de Ciências Biomédicas, Universidade de São Paulo; 2014.

No sul do Brasil, a incidência de tumores adrenocorticias é cerca de 10 a 12 vezes maior do que no resto do mundo, com prevalência para o tipo infantil, devido à ocorrência de uma mutação germinativa no p53. Para compreensão da biologia dos tumores adrenocorticais são utilizados marcadores moleculares que em geral são genes reguladores do ciclo celular. Dentre esses genes, há os genes de resposta primária que são ativados por hormônios e fatores de crescimento, como por exemplo os genes que compõe o fator de transcrição AP-1. Esse é um fator dimérico composto por várias famílias de proteínas que tem em comum domínios essenciais para dimerização e ligação ao DNA. As subfamílias JUN (JUN, JUNB e JUND) e FOS (FOS, FOSB, FRA-1 e FRA-2) são a maioria das proteínas que compõem AP-1. A combinação entre as diferentes proteínas determina a especificidade e afinidade de ligação e os genes que serão regulados. Além disso, os efeitos desses genes é contextodependente, de maneira que podem ser reguladores positivos ou negativos da proliferação celular. Nesse projeto tivemos como hipótese que as proteínas da família JUN, se correlacionam com proteínas reguladoras do ciclo celular em tumores do córtex da suprarrenal, e que poderiam ser utilizados no diagnóstico e prognóstico desse tipo de tumor. Para testar essa hipótese analisamos o padrão de expressão gênica e proteica, respectivamente por ensaios de PCR e immunobloting, da família JUN e do gene FOS em culturas de células de tumores adrenocorticais, obtidos de fragmentos de tumores de pacientes com diferentes características clínicas e anatopatológicas. A análise do padrão de expressão de genes da família JUN e do gene FOS em culturas de células de tumores adrenais por PCR Array, mostrou que esses genes estão pouco expressos nessas culturas, o que foi confirmado em ensaios de qPCR. Não foi possível determinar um padrão de expressão que diferenciasse os tipos de culturas celulares estudados, ou mesmo tumores adultos e pediátricos, através do estudo desse genes. Os tratamentos com ACTH aumentam a expressão da proteina JUN e JUNB, que podem ter certa importância em tumores responsivos à esse hormônio, e que merecem análises futuras.

Palavras Chave: Tumores Adrenocorticais. Fator de Transcrição. AP-1. Expressão Gênica. Genes JUN e FOS. 


\begin{abstract}
Ferreira M. Analysis of JUN and FOS Gene Expression in Adult and Pediatric Adrenocortical Tumor Cells. [master (Thesis in Morphofunctionals Sciences)] São Paulo Instituto de Ciências Biomédicas Universidade de São Paulo.
\end{abstract}

The adrenocortical tumors incidence is 10 to 12 times bigger in the south of Brazil than in the rest of the world.It is more prevalent for childhood type and occurs due to a germinative mutation at p53. In order to have a better comprehension of adrenocortical tumor biology, molecular markers are utillized because they are in general cell cycle regulators. Among these genes, there are the early primary genes which are ativacted by hormones and growth factors, like the genes which compound the transcription factor AP-1. This is a dimeric factor, compound by protein family which has essential domains to dimerization and DNA binding. JUN (JUN, JUNB, JUND) and FOS (FOS, FOSB, FRA1 e FRA 2) proteins are the mainly AP-1 components. The binding specificity and the target genes regulation are determinated by the combination of different proteins. Futhermore, genes effects are context-dependent and could be positive or negative proliferation regulators. In the present study, our hypothesis is that JUN and FOS proteins are correlated with others cell cycle regulatory proteins and could be utilized as a prognose and diagnostic predictor for adrenocortical tumors. The genic and protein profile are analyzed, respectively by PCR assays and Immunobloting from JUN and FOS genes in adrenocortical tumors cultures derived from patients with different clinical and anatopathologic characteristics to hypothesis confirmation. The JUN and FOS gene expression were analyzed by PCR Array and showed that these genes are down regulated in these adrenocortical tumors cells which were confirmed through qPCR analysis. The genes expression analysis wasn't able to stablish a standard of expression between the studied cell cultures or even between adults and pediatric tumors. The ACTH treatments increased JUN and JUNB proteins that may have some significance in responsive tumors to this hormone, and deserve further analysis.

Keywords: Adrenocortical Tumors. Transcription Factor. AP-1. Genic Expression. JUN and FOS genes. 
ACA-Adenoma Adrenocortical

ACC- Carcinoma Adrenocortical

ACT- Tumor Adrenocortical

ACTH- Hormônio Adrenocorticotrófico

AP-1- Ativator Protein 1

BSA- Bovine Serum Albumine

CdKs- Cyclin Dependent Kinase

CREB- CAMP Response-Element Binding Protein

cAMP- Cyclic Monophosfate of Adenosine

DNA- Deoxyribonucleic Acid

DMEM- Meio Eagle Modificado por Dulbecco

ERK- Extracellular Signal-Regulated Kinase

FGF2- Fibroblast Growth Factor 2

HPA- Hypothalamus-Pituitary-Adrenal

IGF2- Insulin like Growth Factor

IGFR1- Insulin like Growth Factor Receptor 1

ITS- Insulin Transferrin Selenium

JNK- JUN NH2 -Terminal Kinases

MAPK- Mitogen Activated Protein Kinases

MC2R- Melanocortin Receptor

PKA- Protein Kinase A

POMC- Pró-opiomelanocortina

RNA- Ribonucleic Acid 
SFB- Bovine Fetal Serum

SF-1- Steroidogenic Factor 1 


\section{LISTA DE FIGURAS}

Figura 1.Desenho de uma secção Longitudinal e Corte Histológico da glândula adrenal de rato (Coloração com H\&E. Aumento de 100x Adaptado de Torres e Lotfi, 2007)

Figura 2. Esquema da cascata de sinalização MAPK que ativa o fator de transcrição AP-1 (Adaptado de Pearson et al., 2001)................................ 23

Figura 3. Esquema das fases do ciclo celular que mostra a relação do fator AP1 e a fase G1 do ciclo celular (Adaptado de Li et al., 2013).

Figura 4.Estrutura em alfa hélice de AP-1(Adaptado de Chinenov, Kerppola, 2001). 26

Figura 5.Clustergrama da expressão dos genes da família JUN e do gene FOS nas culturas de células de tumores adrenocorticais. Diferenças na intensidade de cor determinam a intensidade da expressão, verde (menor expressão) e vermelho (maior expressão). 38

Figura 6 Análise comparativa da expressão do gene JUN em culturas de células de linhagens adrenocorticais adultas (H295R e SW-13), adenomas (ACA) e carcinomas adrenocorticais (ACC) pediátricos $(P)$ e adultos $(A)$, duas recidivas de carcinoma (Rec), uma metástase, uma hiperplasia e uma neoplasia que foram comparados ao pool de tecido de adrenais normais. $n=1$.

Figura 7.Análise comparativa da expressão do gene JUNB em culturas de células de linhagens adrenocorticais adultas (H295R e SW-13), adenomas (ACA) e carcinomas adrenocorticais (ACC) pediátricos $(P)$ e adultos $(A)$, duas recidivas de carcinoma (Rec), uma metástase, uma hiperplasia e uma neoplasia que foram comparados ao pool de tecido de adrenais normais. $n=1$

Figura 8.Análise comparativa da expressão do gene JUND em culturas de células de linhagens adrenocorticais adultas (H295R e SW-13), adenomas (ACA) e carcinomas adrenocorticais (ACC) pediátricos $(P)$ e adultos $(A)$, duas recidivas de carcinoma (Rec), uma metástase, uma hiperplasia e uma neoplasia que foram comparados ao pool de tecido de adrenais normais. $n=1$

Figura 9 Análise comparativa da expressão do gene FOS em culturas de células de linhagens adrenocorticais adultas (H295R e SW-13), adenomas (ACA) e carcinomas adrenocorticais (ACC) pediátricos $(P)$ e adultos $(A)$, duas recidivas de carcinoma $(\mathrm{Rec})$, uma metástase, uma hiperplasia e uma neoplasia que foram comparados ao pool de tecido de adrenais normais. $n=1$ 
Figura 10. Análise da expressão gênica de JUN por qPCR, nas células das recidivas de carcinomas adrenocorticais adultos T24 e T36 e nas células das culturas de adenomas adrenocorticais pediátrico (T7) e adulto (T25). O pool de adrenais normais foi utilizada como calibrador e controle, a $\beta$-Actina foi utilizada como controle endógeno. Análise estatística por teste ANOVA $p<0.001 . n=3 . .42$

Figura 11. Análise da expressão gênica de JUNB por qPCR, nas células das recidivas de carcinomas adrenocorticais adultos T24 e T36 e nas células das culturas de adenomas adrenocorticais pediátrico (T7) e adulto (T25). O pool de adrenais normais foi utilizada como calibrador e controle, a $\beta$-Actina foi utilizada como controle endógeno. Análise estatística por teste ANOVA $p<0.001 . n=3.42$

Figura 12. Análise da expressão gênica de JUND por qPCR, nas células das recidivas de carcinomas adrenocorticais adultos T24 e T36 e nas células das culturas de adenomas adrenocorticais pediátrico (T7) e adulto (T25). O pool de adrenais normais foi utilizada como calibrador e controle, a $\beta$-Actina foi utilizada como controle endógeno. Análise estatística por teste ANOVA ${ }^{* *} p<0.01$ e ${ }^{*} \mathrm{p}<0.05 . \mathrm{n}=3$.

Figura 13.Análise da expressão gênica de FOS por qPCR, nas células das recidivas de carcinomas adrenocorticais adultos T24 e T36 e nas células das culturas de adenomas adrenocorticais pediátrico (T7) e adulto (T25). O pool de adrenais normais foi utilizada como calibrador e controle, a $\beta$-Actina foi utilizada como controle endógeno. Análise estatística por teste ANOVA $p<0.001 . n=3$.

Figura 14.Análise da expressão gênica de JUN em tumores adrenocorticais adultos, sendo uma recidiva (cultura T36- barra lilás) e um adenoma (cultura T25- barra rosa) após estímulo por ACTH $10^{-7} \mathrm{M}$ e Forskolina $10^{-9} \mathrm{M}$. A amostra calibradora foi H295R (barra preta) sem tratamento. Análise estatística por teste ANOVA * $\mathrm{p}<0.05 . \mathrm{n}=3$ 44

Figura 15 Análise da expressão gênica de JUNB em tumores adrenocorticais adultos, sendo uma recidiva (cultura T36- barra lilás) e um adenoma (cultura T25- barra rosa) após estímulo por ACTH $10^{-7} \mathrm{M}$ e Forskolina $10^{-9} \mathrm{M}$. A amostra calibradora foi $\mathrm{H} 295 \mathrm{R}$ (barra preta) sem tratamento. Análise estatística por teste ANOVA ${ }^{*} P<0.05 e{ }^{\star *} P<0.01 . n=3$. 45

Figura 16.Análise da expressão gênica de JUND em tumores adrenocorticais adultos, sendo uma recidiva (cultura T36- barra lilás) e um adenoma (cultura T25- barra rosa) após estímulo por ACTH $10^{-7} \mathrm{M}$ e Forskolina $10^{-9} \mathrm{M}$. A amostra calibradora foi H295R (barra preta) sem tratamento. Análise estatística por teste ANOVA * $p<0.05 . n=3$ 46

Figura 17.Análise da expressão gênica de FOS em tumores adrenocorticais adultos, sendo uma recidiva (cultura T36- barra lilás) e um adenoma (cultura T25- barra rosa) após estímulo por ACTH $10^{-7} \mathrm{M}$ e Forskolina $10^{-9} \mathrm{M}$. A amostra calibradora foi H295R (barra preta) sem tratamento. Análise estatística por teste ANOVA $p<0.001 .{ }^{*} P<0.05 e^{* *} P<0.01 . n=3$. 46 
Figura 18. Expressão da proteína JUN nas células das culturas de tumores adrenocorticais tratadas com $10^{-9} \mathrm{M}$ ACTH e $10^{-7} \mathrm{M}$ Forskolina.Como controle foram utilizadas células da linhagem H295R sem tratamento (ST). Análise estatística por teste $T p=0.0008$ e $p=0.0101$. $n=3$.

Figura 19. Expressão da proteína JUN nas células das culturas de tumores adrenocorticais tratadas com $10^{-9} \mathrm{M}$ ACTH e $10^{-7} \mathrm{M}$ Forskolina. Como controle foram utilizadas células da cultura de recidiva de carcinoma T36 sem tratamento (ST). $\mathrm{n}=1$ 48

Figura 20.Expressão da proteína JUNB nas células das culturas de tumores adrenocorticais tratadas com $10^{-9} \mathrm{M}$ ACTH e $10^{-7} \mathrm{M}$ Forskolina.Como controle foram utilizadas células da linhagem H295R sem tratamento (ST). Análise estatística por teste $T p=0.0099$. $n=3$.

Figura 21.Expressão da proteína JUNB nas células das culturas de tumores adrenocorticais tratadas com $10^{-9} \mathrm{M}$ ACTH e $10^{-7} \mathrm{M}$ Forskolina.Como controle foram utilizadas células da cultura de recidiva de carcinoma T36 sem tratamento (ST). 50

Figura 22.Expressão da proteína JUND nas células das culturas de tumores adrenocorticais tratadas com $10^{-9} \mathrm{M}$ ACTH e $10^{-7} \mathrm{M}$ Forskolina.Como controle foram utilizadas células da linhagem H295R sem tratamento (ST). Análise estatística por teste $T p=0.0053 n=3$. 51

Figura 23. Expressão da proteína JUND nas células das culturas de tumores adrenocorticais tratadas com $10^{-9} \mathrm{M}$ ACTH e $10^{-7} \mathrm{M}$ Forskolina.Como controle foram utilizadas células da cultura de recidiva de carcinoma T36 sem tratamento (ST). $\mathrm{n}=1$ 52

Figura 24.Expressão da proteína FOS nas células das culturas de tumores adrenocorticais tratadas com $10^{-9} \mathrm{M}$ ACTH e $10^{-7} \mathrm{M}$ Forskolina.Como controle foram utilizadas células da linhagem H295R sem tratamento (ST). Análise estatística por teste $T \mathrm{n}=3$. 53

Figura 25.Expressão da proteína FOS nas células das culturas de tumores adrenocorticais tratadas com $10^{-9} \mathrm{M}$ ACTH e $10^{-7} \mathrm{M}$ Forskolina.Como controle foram utilizadas células da cultura de recidiva de carcinoma T36 sem tratamento (ST). 


\section{LISTA DE TABELAS}

Tabela 1. Relação das culturas de células obtidas de tumores adrenocorticais.

Tabela 2. Sequências dos primers utilizados ............................................. 35

Tabela A. 1 Genes das placas de PCR Array ............................................ 72 


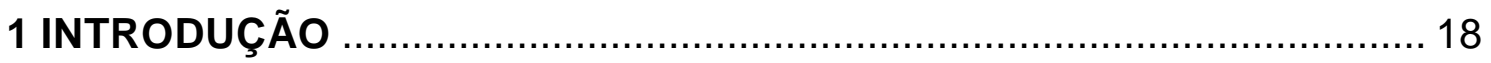

2 OBJETIVOS

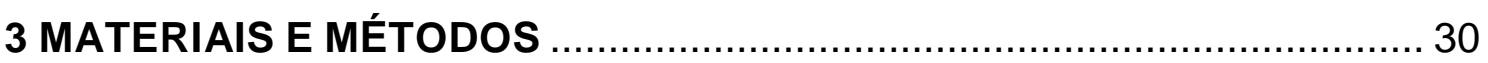

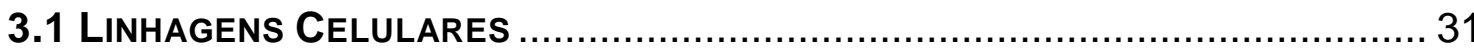

3.2 Culturas de CÉlULAS de tUmores ADRENocorticais de PACIENTES ....... 31

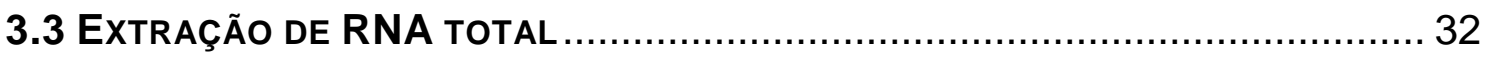

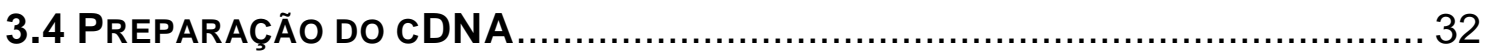

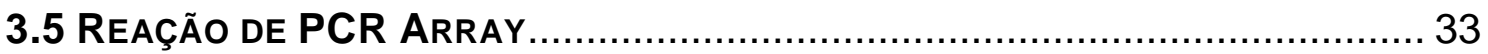

3.6 PCR QUANTITATIVO EM TEMPO REAL (QPCR) …................................... 33

3.7 REAÇÃo DE PCR QUANTITATIVO EM TEMPO REAL (QPCR)......................... 34

3.8 ANÁlise da eXPRESSÃo aPós estímulo com ACTH e Forskolina POR QPCR

3.9 Extração, QuANTIFICAÇão, SEParação da PROtEína total E REAÇão de

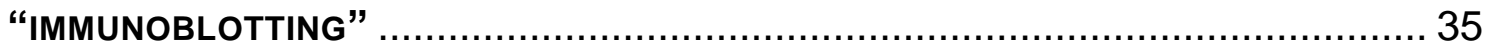

4 RESULTADOS

4.1 ANÁlise da eXPRESSÃo dos GENES da família JUN E do GENE FOS NAS CULTURAS DE CÉLULAS DE TUMORES ADRENOCORTICAIS ............................... 38

4.2 VALIDAÇÃo dA EXPRESSÃo dOS GENES dA FAMILIA JUN E DO GENE FOS POR PCR QUANTITATIVO

4.3 ANÁlise dA EXPRESSÃo dOS GENES dA FAMILIA JUN E do GENE FOS APÓS ESTÍMULO COM ACTH E FORSKOLINA EM CÉLULAS DE TUMORES ADRENOCORTICAIS 44

4.4 ANalise da expressão das proteinas da família JUN e da proteína FOS NAS CULTURAS DAS CÉLULAS ADRENOCORTICAIS .................................... 47

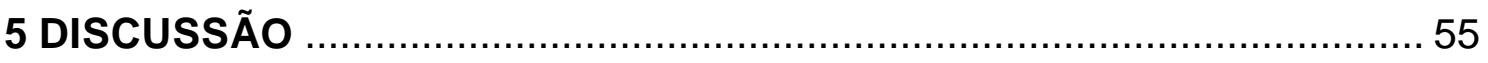

6 CONCLUSÕES

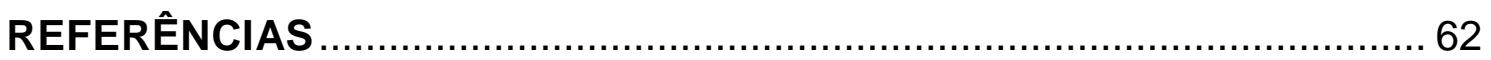

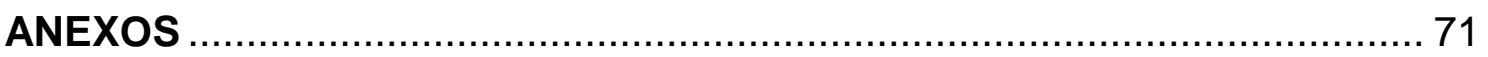


ANEXO A. Tabela de genes das placas de PCR Array 
1 INTRODUÇÃO 
Nos mamíferos, as suprarrenais são glândulas endócrinas com formato triangular, envoltas por uma cápsula fibrosa e posicionadas acima dos rins, na cavidade abdominal. Cada glândula é composta por duas regiões histologicamente distintas, o córtex e a medula adrenal. O cortex é dividido em três zonas concêntricas: glomerulosa, fasciculada e reticulada (McNicol, 1992). Através de uma ação coordenada dos citocromos P450 e de desidrogenases, o córtex da suprarrenal produz hormônios esteroides, utilizando o colesterol como substrato (Simpson et al., 1992). A zona glomerulosa é a principal responsável pela secreção dos mineralocorticoides, enquanto as zonas fasciculada e reticulada são as responsáveis respectivamente, pela síntese do cortisol e dos hormônios sexuais humanos (Figura1).
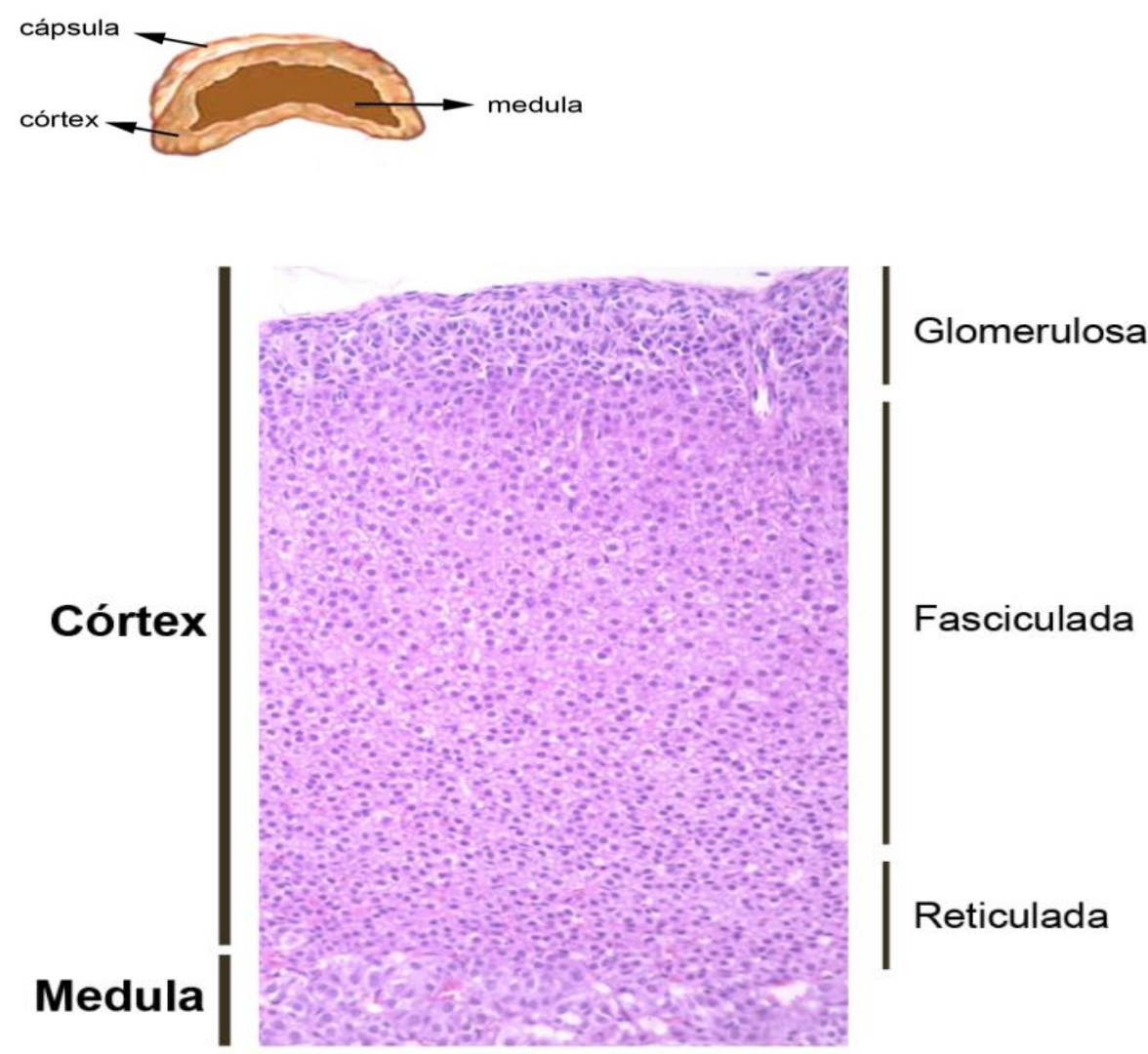

Figura 1.Desenho de uma secção Longitudinal e Corte Histológico da glândula adrenal de rato (Coloração com H\&E. Aumento de 100× Adaptado de Torres e Lotfi, 2007).

Em condições fisiológicas normais, os principais estímulos para manutenção do trofismo, proliferação celular e síntese dos mineralocorticóides e glicocorticóides são, respectivamente o sistema renina-angiotensina, por estímulo da Angiotensina II e o eixo hipotálamo-hipófise-adrenal, através do ACTH (hormônio adrenocorticotrófico). O ACTH é um peptídeo composto por 
39 aminoácidos, originado apartir do processamento da pró-opiomelanocortina (POMC) (White, Cribson, 1998) e tem como função estimular a esteroidogênese e está envolvido na manutenção do córtex da adrenal (Ogishima et al., 1989). Nas glândulas adrenais o ACTH se liga no receptor de melanocortina, o receptor MC2R, que é um integrante da família de receptores da melanocortina, uma proteína transmembranica de sete hélices acoplada à proteína $G$ (Xing $Y$ et al., 2010). Disfunções destes fatores e funções têm sido encontradas em patologias caracterizadas por hipersecreção hormonal e/ou descontrole na proliferação celular.

De uma maneira geral, as patologias da glândula adrenal podem ser classificadas como hiperplasias, que podem ser macro e micronodular, e as neoplasias, os adenomas e carcinomas. A incidência e prevalência dos tumores adrenocorticais (ACT) tem aumentado devido aos achados acidentais de massas adrenais durante exames de análise de imagem. Essa prevalência varia de $0,6 \%$ a $2 \%$ em pacientes acima dos 50 anos (Stojadinovic et al., 2003). No entanto, somente uma pequena proporção desses tumores causa alterações endócrinas e menos que $5 \%$ são malignos (Angeli et al., 1997; Bornstein et al., 1999). A incidência anual de carcinomas adrenocorticais (ACC) é de 1 a 2 casos por milhão de habitantes e é tipicamente diagnosticado em adultos na faixa dos 40 e 50 anos, mais comum em mulheres, mas também pode ser encontrado em crianças. No sul do Brasil, a incidência de ACT aumenta para 12 casos por milhão por ano com prevalência para o tipo infantil, devido à ocorrência de uma mutação germinativa na proteína do gene supressor de tumor, o gene TP53 (Almeida, Latronico, 2007; Ribeiro et al., 2001). De uma maneira geral, carcinomas adrenocorticais são diagnosticados tardiamente apresentando metástases disseminadas, cujo prognóstico é limitado e com uma taxa de sobrevivência abaixo dos 35\% em cinco anos (Abiven et al., 2006; Allolio et al., 2004; Libe et al., 2007; Luton et al., 1990). Apesar dos progressos obtidos, a compreensão da biologia dos tumores adrenocorticais é ainda incompleta.

Clinicamente os adenomas (ACA) e os carcinomas (ACC) adrenocorticais se apresentam de maneira semelhante. A distinção entre eles é feita através de um escore de critérios anátomo-patológicos conhecidos como escore de Weiss. Esses critérios são alta taxa mitótica, alto grau nuclear, 
mitoses atípicas, célula claras que compreendem $25 \%$ ou menos do tumor, arquitetura difusa, necrose, invasão de estrutura venosa, invasão de estrutura sinusoidal e invasão da cápsula do tumor (Weiss, 2009). Em situações limítrofes e principalmente nos tumores pediátricos, tais critérios apresentam limitações (Mendonça et al., 1995; Wieneke et al., 2003; Weiss et al., 1989). Em tumores pediátricos, foram encontrados alguns marcadores de malignidade que sugerem que apesar de se apresentarem clinicamente benignos, há a presença de achados histológicos que são associados à malignidade, tais como, necrose; invasão capsular e vascular; pleomorfismo nuclear e mitoses atípicas. Além disso, há dois critérios que são preditores de sobrevivência e portanto, importantes na diferenciação entre carcinomas e adenomas e são a ocorrência de recidivas e metástases (Weiss, 2009). Bugg e colaboradores (1994) constataram que 9 de 16 carcinomas adrenocorticais altamente agressivos, e 5 de 27 carcinomas adrenocorticais com um baixo nível de agressividade apresentaram recidivas e metástases. Em relação aos adenomas, em um coorte de 11 adenomas adrenocorticais, nenhum apresentou recidiva e/ou metástases.(Weiss et al., 2009; Wieneke et al., 2003). O peso, o tamanho e a coloração dos tumores também são critérios importantes. Os adenomas geralmente pesam menos que $50 \mathrm{~g}$, possuem de 5 a $6 \mathrm{~cm}^{3}$ e são mais amarelos, enquanto que os carcinomas podem pesar até $500 \mathrm{~g}$, medem até $200 \mathrm{~cm}^{3}$ e apresentam coloração amarelo-alaranjado ou bege rosado (Tissier et al., 2010). Nas últimas décadas uma série de estudos envolvendo aspectos histológicos e moleculares têm sido realizados para encontrar marcadores de malignidade mais precisos. Atualmente os marcadores histológicos e moleculares utilizados em estudos são, a proteína Ki-67, que apresenta expressão consistentemente maior nos carcinomas quando comparado aos adenomas (Goldblum et al., 1993; Tissier et al., 2010), a mutação do gene p53, que ocorre devido a perda de heterozigosidade em TP53 e cuja proteína está 25\% mais expressa em carcinomas (Ohgaki et al., 1993; Reincke et al., 1994; Libe et al., 2007; Lin et al., 1994;), o fator de crescimento insulina-like do tipo 2 (IGF2) que é um importante fator de crescimento fetal e está $90 \%$ mais expresso em carcinomas (Tissier et al., 2010), o ACTH, que está diretamente envolvido no aumento da expressão de IGF2 e IGFR1, ambos estão diretamente relacionados a tumorigênese 
(Ilvesmaki et al., 1993; Gao et al., 2002; Liu et al., 1995; Weber et al, 1997), a ciclina $\mathrm{E}$, que é um importante regulador do ciclo celular, e cujos níveis estão aumentados em carcinomas em relação aos adenomas (Bourcigaux et al., 2000; Tissier et al., 2005), a via clássica Wnt/ß-catenina que é ativada em carcinomas e adenomas, além disso o acúmulo de $\beta$-catenina é maior nos adenomas que em carcinomas (Gaujoux et al, 2008; Tissier et al, 2005).

Em uma análise geral dos estudos sobre a utilização desses marcadores, Giordano (2010) concluiu que os carcinomas adrenocorticais podem, através de marcadores moleculares, serem classificados em subgrupos que podem ser relevantes em termos de prognóstico. Além disso a análise da expressão gênica baseada no estudo de um pequeno número de genes informativos pode auxiliar na rotina clinico-patológica, e que finalmente genes relacionados com ciclo celular e consequentemente com a proliferação celular são importantes na tumorigênese adrenocortical e precisam ser estudados.

A indução da proliferação celular está relacionada à ação de hormônios e fatores de crescimento, que ao se ligarem a receptores específicos desencadeiam uma cascata de sinalização, que ocorre na maioira das vezes por fosforilação, e alteram a expressão de genes específicos (Pardee, 1989; Scheer, 1994). A superfamília das MAPKs é composta por três famílias de proteínas quinases, as ERKs que são proteínas reguladas por sinais externos; as JNKs que são quinases NH2 terminal de JUN e a p38/MAPK (Cowan, Story, 2003). Ao final de uma cascata de sinalização proteínas modificadas por diferentes níveis de fosforilação são direcionadas ao núcleo e tem a capacidade de se ligar à regiões alvo do DNA, e modificar o padrão de expressão gênica das células (Cobb, Goldsmith, 1995; Eferl, Wagmer, 2003; Pearson et al., 2001; Seger, Krebs, 1995). Em sua maioria esses genes codificam proteínas com a função de regular a transcrição gênica de outros genes, sendo, portanto, importantes fatores de transcrição que podem ter como função estimular a progressão do ciclo celular (Healy et al., 2012; Scheer, 1994) como exemplificado na Figura 2. 


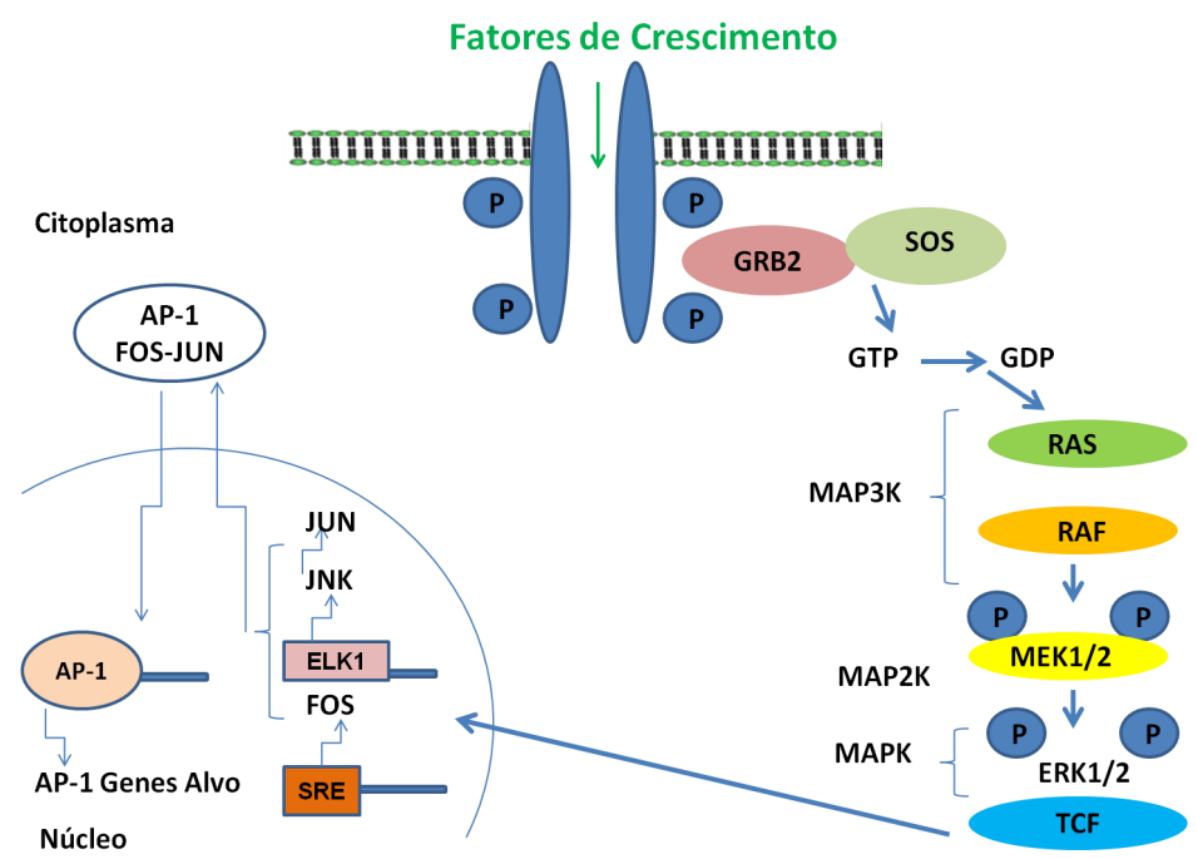

Figura 2. Esquema da cascata de sinalização MAPK que ativa o fator de transcrição AP-1 (Adaptado de Pearson et al., 2001).

O ciclo celular ocorre em fases (gaps) conhecidas como fases $\mathrm{G} 1$ (Gap1), G2 (Gap2), S (Sintese e duplicação do DNA) e M (Mitose, citocinese e divisão celular) do ciclo celular. Na fase G1 do ciclo celular, que pode ser a mais longa, as células duplicam suas organelas e através da produção de proteinas e fatores de transcrição se preparam para a duplicação do DNA ou fase $S$ do ciclo celular. Ao final da fase $G 1$ existe um ponto de restrição ou de checagem (R1), que pode interromper o ciclo celular caso as proteínas e fatores de crescimento necessários para a entrada em $S$ não se completaram (Blagosklonny, Pardee, 2002; Dubavka, Scott, 2000). Dentre os genes que são expressos nessa fase do ciclo celular estão os genes de resposta primária, que não requerem nova síntese proteica para sua expressão, garantem o padrão de expressão diferencial dos genes de resposta secundária, como por exemplo as ciclinas dependentes de quinases (CDKs) (Herschman,1991). As ciclinas D (D1, D2 e D3) são as ciclinas expressas na fase G1 do ciclo celular e se ligam às com CDK4 e 6 cujo complexo irá estimular a expressão da ciclina $E$ que por sua vez se complexa com a CDK2 (Sherr, 1993). A formação dos complexos de ciclinas $D$ e CDKs também bloqueiam o efeito inibitório das proteinas CKls (cyclin dependent kinase inhibitors) o que permite a fosforilação da proteína $\mathrm{Rb}$ (retinoblastoma) que libera o fator de transcrição E2F que ativa genes que 
permitem a transição para a fase de sintese de DNA, a fase $S$ (Sherr et al., 1999; Herschman,1991). Se as condições extracelulares não forem favoráveis para a entrada em G1, a célula entra em um estado quiescente que é a fase G0, uma etapa que se interpõe às fases do ciclo, como um anexo da interfase (fase S) (Pardee, 1974). Após a síntese do DNA, a célula inicia o preparo para a mitose que é a fase G2, em que a célula apresenta conteúdo duplicado de material genético. Nessa fase há outro ponto de restrição (R2) e ocorre a expressão de p53 que é o gene responsável por detectar erros de replicação e material genético não duplicado (Nigg et al., 2012). A fase siguinte é a fase $M$ aonde ocorre a condensação e segregação dos cromossomos e desorganização do envelope nuclear. Após a segregação dos cromossomos, a membrana nuclear é reorganizada e então ocorre a citocinese que é a divisão do material genético (Pardee,1974).

Portanto, os genes de resposta primária são um grupo de genes que são induzidos por sinais celulares extrínsecos e intrínsecos sem necessidade de síntese proteica para sua expressão. Esses genes que primeiro respondem à essa onda de sinalizacão tem um papel chave na resposta biológica que inclui plasticidade e sobrevivência neuronal, resposta ao estresse cardíaco, resposta imune inata e adaptativa, metabolismo da glicose e transformação oncogênica (Fowler et al., 2011).

Dentre os genes de resposta primária estão descritos os genes que codificam proteínas que irão formar o fator de transcrição AP-1 (activator protein 1) (Figura 3). 


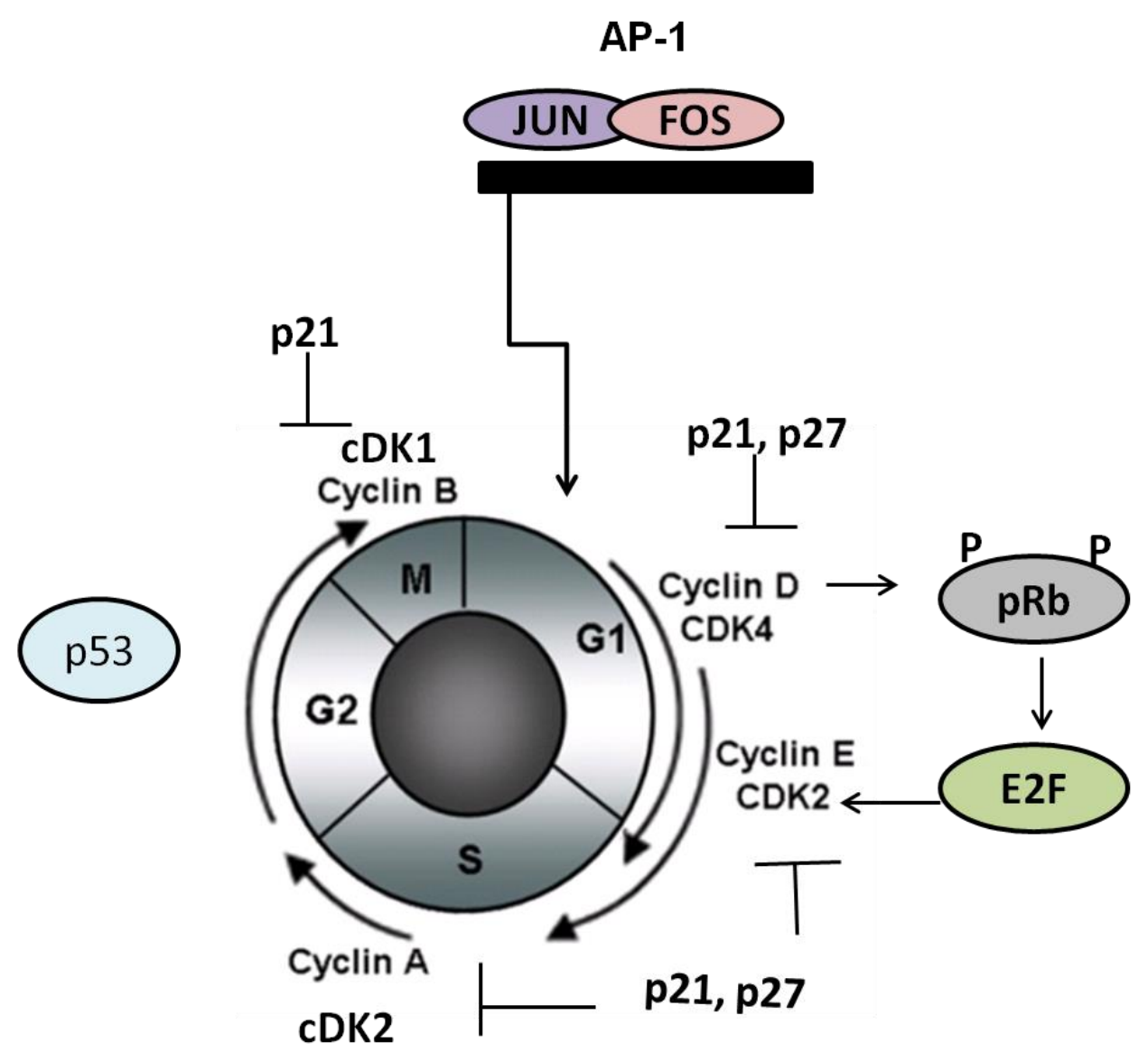

Figura 3. Esquema das fases do ciclo celular que mostra a relação do fator AP-1 e a fase G1 do ciclo celular (Adaptado de Li et al., 2013).

As proteínas que formam AP-1 têm em comum domínios zíper de leucina básica (bZIP) essenciais para dimerização e ligação ao DNA. AP-1 pode ser composto pelas proteínas JUN (JUN, JUNB e JUND) e FOS (FOS, FOSB, FRA-1 e FRA-2), além das proteínas que podem dimerizar com JUN e FOS, tais como JDP 1 e 2 (Jun dimerization partners), proteínas ATF (activating transcription factor) ATF2, LRF1/ATF3, B-ATF. Há também outro grupo de proteínas AP-1 que é constituido pelas proteinas da família MAF (musculo aponeurotic fibrosarcoma), que inclui C-MAF, MAFB, MAFA,

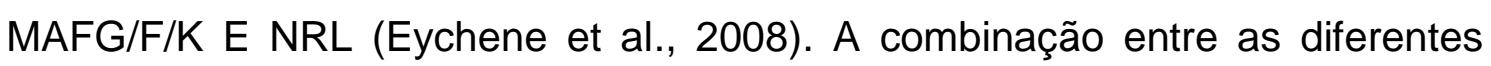
proteínas determina a especificidade e afinidade de ligação, e consequentemente os genes que serão regulados (Hess et al., 2004).

A maior afinidade de ligação e heterodimerização ocorrem entre JUN e FOS; pois JUN pode formar tanto homodímeros como heterodímeros, e é capaz de formar dímeros estáveis que se ligam à regiões consenso de AP-1. 
Em contrapartida FOS não é capaz de formar ligações estáveis enquanto homodímero, e por isso forma heterodímeros com JUN para se ligar ao DNA (Figura 4). As proteínas MAF (V-MAF, C-MAF E NRL) podem heterodimerizar com JUN e FOS (Swaroop et al.,1992; Nishizawa et al.,1989), enquanto MAFB, MAFF, MAFG E MAF K só podem heterodimerizar com FOS. As proteínas ATF podem formar homo e heterodímeros com JUN e se ligam preferencialmente aos elementos responsivos de AMP cíclico (CRE) (Shaulian, Karin, 2001). Outra proteína relacionada a região $\mathrm{CRE}$, a proteína de ligação CREB (CAMP responsive element-binding) interage com JUN, JUNB e FOS, enquanto que CREB 2 forma apenas heterodímeros com JUN (Angel, Karin, 1990).

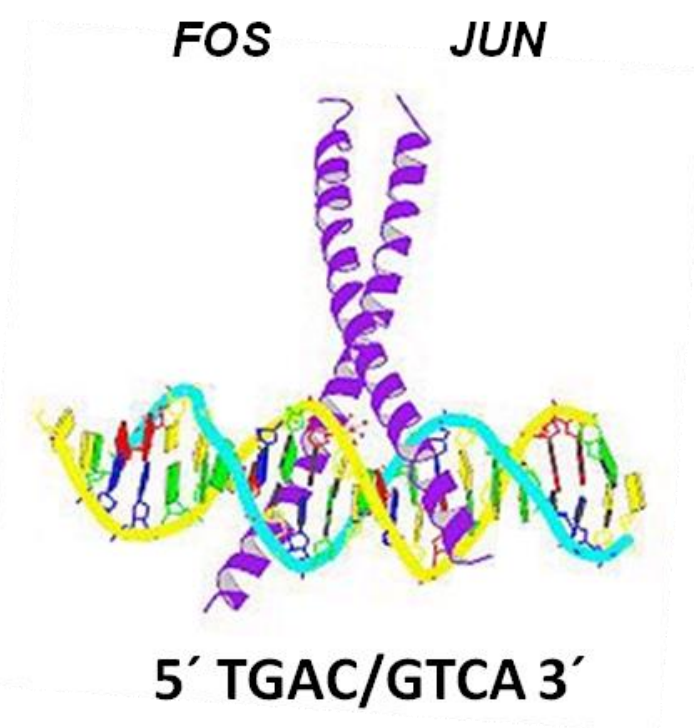

Figura 4.Estrutura em alfa hélice de AP-1(Adaptado de Chinenov, Kerppola, 2001).

Resultados da ação do hormônio adrenocorticotropico (ACTH) e do éster de forbol (PMA) em células de tumor adrenocortical de camundongo, linhagem Y1, resulta na expressão de várias proteínas da família FOS e JUN e na progessão do ciclo celular por vias diferentes da via clássica da ação do ACTH, a via cAMP/PKA (Kimura et al., 1993; Lotfi et al., 1997; Lotfi \& Armelin, 1998; Lotfi \& Armelin, 2001). Trabalhos do nosso grupo que utilizaram diferentes modelos experimentais em ratos, infusão in situ (Baccaro et al., 2007) e hipofisectomia (Torres, Lotfi, 2007), mostraram o papel do fator de transcrição AP-1 na resposta proliferativa do ACTH e do fator de crescimento de fibroblastos do tipo 2 (FGF2) no córtex adrenal in vivo. Nesses trabalhos a composição de AP-1 foi analisada e a relação entre a expressão de JUN e FOS 
com a indução da proliferação foi estabelecida. Além disso, FOS e JUN, podem estimular a esteroidogênese nas células adrenais se ligando no promotor do gene que codifica a proteína StAR (Steroidogenic acute regulatory protein), proteína transportadora de colesterol na (Rincon et al., 2009).

A proteína JUN parece estar envolvida na progressão do tumor por aumentar a proliferação e proteger as células da apoptose (Shaulian et al., 2010). JUNB pode ser um oncogene como um supressor de tumor, enquanto a relevância de JUND como regulador de crescimento é ainda pouco clara (Shaulian et al., 2010).

AP-1 será definido como oncogene ou supressor de tumor em função do tipo celular, do estado de diferenciação celular, estágio do tumor e seu background genético. Esse efeito ocorre devido à capacidade de fator de transcrição regular genes envolvidos na proliferação, diferenciação, apoptose, angiogênese e metástase, o que lhe confere potencialmente características de alvo para terapia antitumoral (Shaulian et al., 2010). Diante do apresentado tivemos como hipótese que as proteínas da família JUN (JUN, JUNB e JUND) podem ser proteínas reguladoras do ciclo celular em tumores da suprarrenal, e que poderiam ser utilizados no diagnóstico e prognóstico desse tipo de tumor, ou mesmo, potencialmente, alvos em terapia. 
2 OBJETIVOS 
Analisar o padrão de expressão de genes da família JUN e do gene FOS em culturas de células de tumores adrenais por PCR Array.

Validar os níveis de expressão dos genes da família Jun e do gene Fos diferencialmente expressos por PCR quantitativo ( $\mathrm{PPCR}$ ), em condições normais e após indução com ACTH e Forskolina.

Analisar os níveis de expressão das proteinas da familia JUN e da proteina FOS por imunoblotting. 
3 MATERIAIS E MÉTODOS 


\subsection{Linhagens Celulares}

Foram utilizadas as linhagens de carcinoma adrenocortical humano, as células $\mathrm{NCl}-\mathrm{H} 295 \mathrm{R}$ e as células SW-13, estabelecidas, respectivamente, por Gazdar e colaboradores (1990) e por Leibovitz e colaboradores (1973).

\subsection{Culturas de CÉlULAS DE TUMORES ADRENOCORTICAIS DE PACIENTES}

As culturas de células de tumores de adrenal que foram utilizadas foram culturas de células de adenomas e carcinomas pediátricos e adultos obtidas de fragmentos de tumores de pacientes do sexo feminino que foram enviados pelo laboratório de hormônios e genética molecular do Hospital das Clínicas da Faculdade de Medicina da Universidade de São Paulo.

Tabela 1. Relação das culturas de células obtidas de tumores adrenocorticais.

\begin{tabular}{|cll|}
\hline Culturas & Idade & Anatopatológico \\
\hline T7 & $1 \mathrm{a} 7 \mathrm{~m}$ & Adenoma Pediátrico \\
\hline T47 & $11 \mathrm{~m}$ & Adenome Pediátrico \\
T25 & $16 \mathrm{a}$ & Adenoma Adulto \\
T105 & $4 \mathrm{a}$ & Carcinoma Pediátrico \\
T83 & $31 \mathrm{a}$ & Carcinoma Adulto \\
T53 & $22 \mathrm{a}$ & Carcinoma Adulto \\
T20 & $23 \mathrm{a}$ & Carcinoma Adulto \\
T36 & 38 & Recidiva \\
T24 & $22^{\mathrm{a}}$ & Recidiva \\
T19 & $17 \mathrm{a}$ & Neoplasia \\
T16 & $50 \mathrm{a}$ & Hiperplasia \\
\hline
\end{tabular}




\subsection{EXTRAÇÃo DE RNA TOTAL}

Foram plaqueadas $9 \times 10^{5}$ células em placas de Petri com meios de cultura DMEM, RPMI ou Leibovitz, dependendo do tipo celular, e $2 \%$ ou $10 \%$ de soro fetal bovino (SFB) ou ainda suplementado com Insulina, Transferrina e Selênio (ITS). Após 24 horas do plaqueamento foi adicionado $1 \mathrm{ml}$ de TRIzol® (Invitrogen, São Paulo, Brasil) para a extração do RNA total, seguido da raspagem das células para obtenção do homogenato. A ele foi adicionado 200 $\mu$ l de clorofórmio, que após centrifugação (12.000 rpm; à $-4 \stackrel{\circ}{ } \mathrm{C}$ por 15 minutos) e separação em três fases, teve a fase incolor, contendo o RNA, recolhida. Em seguida foi adicionado $500 \mu \mathrm{l}$ de álcool isopropílico seguido de centrifugação (12.000 rpm; à $-4{ }^{\circ} \mathrm{C}$ por 15 minutos). O precipitado contendo o RNA foi lavado com etanol 75\%, centrifugado por 15 minutos; $12.000 \mathrm{rpm}$; à $-4 \stackrel{\circ}{\mathrm{C}} \mathrm{e}$ solubilizado em água DEPC (Dietil Pirocarbonato). As amostras foram mantidas à $-4{ }^{\circ} \mathrm{C}$ "overnight" em câmara fria sob constante agitação e após esse período foi armazenada à $-80 \stackrel{\circ}{\circ}$. O RNA total obtido foi quantificado em espectrofotômetro em comprimento de onda A260/280nm e avaliado quanto à integridade em gel de agarose.

\subsection{Preparação do CDNA}

A partir de $1 \mu \mathrm{g}$ do RNA total foi obtido o cDNA a partir da utilização do "kit" fornecido pelo fabricante das placas de "PCR array" (SABiosciences Qiagen, Germantown, MD, EUA). Foi preparado uma solução de eliminação de DNA Genômico composto por $2 \mu$ de buffer GE (5X gDNA Elimination Buffer), $1 \mu \mathrm{g}$ do RNA total e $7 \mu \mathrm{l}$ RNAse Free Water. Essa solução foi incubada no termociclador por 5 minutos à $42{ }^{\circ} \mathrm{C}$ e colocado no gelo por 1 minuto. Após resfriamento total do conteúdo, foi adicionado uma solução contendo a transcrição reversa, composta por $4 \mu \mathrm{l}$ de 5X Buffer BC3, $1 \mu$ l Control P2, $2 \mu \mathrm{l}$ RE3 reverse Transcriptase Mix e $3 \mu l$ de RNAse Free Water, foi homogeneizado e incubada à $42{ }^{\circ} \mathrm{C}$ por 15 minutos, e em seguida à $95^{\circ} \mathrm{C}$ por 5 minutos. Ao final deste processo foi adicionado $91 \mu$ de RNAse Free Water e a amostra foi estocada à $-20{ }^{\circ} \mathrm{C}$ até 0 momento da preparação da placa de PCR Array. 


\subsection{ReAÇÃo de PCR ArRay}

Foram utilizadas as placas de "PCR Array" $\mathrm{RT}^{2}$ Profiler $^{\mathrm{TM}} \mathrm{PCR}$ Array Human Oncogenes \& Tumor Supressor Genes (PAHS-502A), contendo 96 genes separados em grupos. O cDNA obtido foi misturado a $1,35 \mathrm{ml}$ do reagente SYBR Green MIX e 1,248 ml de RNAse Free Water. Após agitação a solução foi adicionado à placa de PCR array em um volume final de $25 \mu \mathrm{l}$ por poço. A placa foi analisada em um aparelho de PCR tempo real (ABI 7500 Applied Biosystems) e os dados obtidos foram analisados através do método da determinação da variação do $2^{-\Delta \Delta \mathrm{Ct}}$ Foram consideradas relevantes as variações de transcrições gênicas alteradas, dependendo da comparação realizada, no mínimo uma vez e meia em relação ao controle utilizado denominado Fold Change.

\subsection{PCR QUANTITATIVO EM TEMPO REAL (QPCR)}

O cDNA foi sintetizado utilizando o Kit de M-MLV RT (Moloney Murine Leukemia Virus Reverse Transcriptase - usada para sintetizar uma fita complementar para o DNA na presença de um RNA e de um primer). Para a primeira reação foram utilizados $1 \mu \mathrm{l}$ do oligo (dT) 12-18 (500 $\mu \mathrm{g} / \mathrm{ml}) ; 1 \mu \mathrm{g}$ do RNA total; $1 \mu l 10 \mathrm{mM}$ dNTP Mix (10 mM - dATP, dGTP, dCTP e dTTP em pH neutro) e o volume foi completado pra $12 \mu \mathrm{l}$ com água destilada ultrapura. Os componentes foram homogeneizados e aquecidos a $65 \stackrel{\circ}{\circ} \mathrm{C}$ por 5 minutos, após o aquecimento a reação foi rapidamente colocada no gelo, os componentes do tubo foram recuperados por uma breve microcentrifugação e em seguida foram adicionados $4 \mu \mathrm{l}$ do tampão 5x First Strand Buffer; $2 \mu \mathrm{l}$ de $0.1 \mathrm{M}$ DTT; $1 \mu \mathrm{l}$ de RNaseOUT TM Recombinant Ribonuclease Inhibitor (40 unidades/ $\mu$ ), todos os componentes do tubo foram homogeneizados e incubados a $37 \stackrel{\circ}{\mathrm{C}}$ por 2 minutos; foi adicionado $1 \mu \mathrm{l}$ (200 unidades) de M-MLV RT, que foram ressuspendidos delicadamente e em seguida todo o conteúdo do tubo foi incubado por 50 minutos a $37 \stackrel{\circ}{\circ}$, por último a reação foi inativada por aquecimento a $70 \stackrel{\circ}{\mathrm{C}}$ por 15 minutos. A amostra foi armazenada em freezer -80 C para posterior utilização na reação de PCR. 


\subsection{REAÇÃo de PCR QUANTITATIVO EM TEMPO REAL (QPCR)}

Para realização do PCR quantitativo em tempo real, foi utilizado o Kit Platinun SYBR Green qPCR SuperMix-UDG (Life Technologies), uma composição de reagentes necessários para a amplificação e detecção do DNA no PCR quantitativo em tempo real. O SYBR Green I é uma sonda fluorescente que possui uma sensibilidade específica para quantificação de sequências alvo. A reação, que foi preparada para um volume final de $50 \mu \mathrm{l}$, se iniciou com a adição de $25 \mu \mathrm{l}$ do Platinum SYBR Green q PCR SuperMix- UDG; $1 \mu \mathrm{l}$ do Forward primer a $10 \mu \mathrm{M}$ e $1 \mu \mathrm{l}$ do Reverse primer a $10 \mu \mathrm{M}$. As sequencias de primers utilizados estão na tabela 1. A sonda fluorescente ROX Reference Dye foi adicionada de forma proporcional ao volume final da reação, ou seja, $1 \mu \mathrm{l}$ para cada $50 \mu \mathrm{l}$. A concentração e volume de cDNA utilizada foi de $1 \mu \mathrm{g}-1 \mu \mathrm{l}$ que foi previamente sintetizado. Para finalizar foi adicionado $1 \mu \mathrm{l} \mathrm{de} \mathrm{MgCl} 2$ e $20 \mu \mathrm{l}$ de água DEPC. Todo o conteúdo foi colocado em tubo de $0,2 \mathrm{ml}$ e brevemente centrifugado para precipitação de todo o conteúdo; em seguida os tubos foram submetidos a uma variação de temperatura para amplificação dos

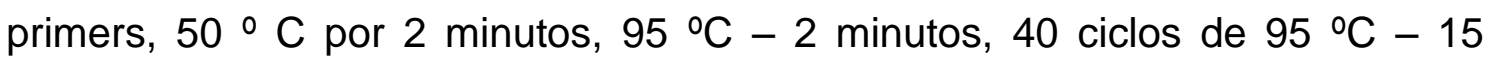
segundos, $60 \cong \mathrm{C}-30$ segundos. A reação foi analisada em um aparelho de PCR tempo real (ABI 7500 Applied Biosystems) e os dados obtidos foram analisados através do método da determinação da variação do $2^{-\Delta \Delta C t} \mathrm{e}$ apresentados na forma de gráficos. 
Tabela 2. Sequências dos primers utilizados

\begin{tabular}{crc}
\hline Gene & Sequência Forward & Sequência Reverse \\
\hline JUN & GCCAACTCATGCTAACGCAG & CTCTCCGTCGCAACTTGTCA \\
JUNB & AACAGCCCTTCTACCACGAC & CAGGCTCGGTTTCAGGAGTT \\
FOS & GGGGCAAGGTGGAACAGTTA & AGTTGGTCTGTCTCCGCTTG \\
B-Actina & GATGAGATTGGCATGGCTTT & CACCTTCACCGTTCCAGTTT \\
\hline
\end{tabular}

\subsection{ANÁlise da EXPRESSÃo APós eStímUlo COM ACTH E ForsKolina POR QPCR}

Após 48 horas do plaqueamento as células foram expostas a um tratamento de uma hora com ACTH $10^{-7} \mathrm{M}$ e Forskolina $10^{-9} \mathrm{M}$, em seguida foi realizada a extração do RNA conforme o protocolo de extração descrito acima e a síntese do cDNA. O cDNA foi aplicado na placa de 96 poços e submetido a reação de qPCR com Sybr Green.

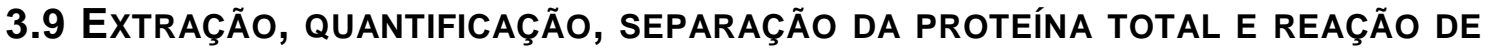 "IMMUNOBLOTTING"}

Após 24 horas do plaqueamento, as células foram lisadas em tampão de lise RIPA (TrisHCL $50 \mathrm{mM}$; deoxicolato de sódio 0,5\%; NP40 1\%; $\mathrm{NaCl} 150$ $\mathrm{mM}$; SDS $0,1 \%$; NaF $50 \mathrm{mM}$ ) e inibidores de proteases e fosfatases (Ortovanadato $1 \mathrm{mM}$; PMSF $1 \mathrm{mM}$; Aprotinina $2 \mu \mathrm{g} / \mathrm{ml}$; Pepstatina $2 \mu \mathrm{g} / \mathrm{ml}$; Leupeptina $2 \mu \mathrm{g} / \mathrm{ml}$ ). O lisado recolhido foi clareado por centrifugação a 14.000 rpm à $-4 \stackrel{\circ}{\circ}$, por 15 min, aliquotado e estocado imediatamente em freezer a -80 ${ }^{\circ} \mathrm{C}$. A quantificação da proteína total foi realizada com $2 \mu \mathrm{l}$ do lisado mais 198 $\mu \mathrm{l}$ de solução de Bradford (Bio-Rad) diluído, em espectrofotômetro em comprimento de onda de $595 \mathrm{~nm}$. Como padrão de calibração do aparelho e das amostras foi utilizada uma curva de concentrações definidas de albumina bovina (BSA-Sigma). Depois de quantificadas as amostras foram adicionadas a um tampão (Tris- $\mathrm{HCl}$ pH 6,8, glicerol, SDS, $\beta$-mercaptoetanol e azul de bromofenol), desnaturadas a $100^{\circ} \mathrm{C}$ por $5 \mathrm{~min}$, antes de serem aplicadas em 
$12 \%$ gel de poliacrilamida desnaturante (SDS-PAGE). Foi utilizado um padrão de peso molecular para identificação das bandas. As proteínas retidas no gel e separadas conforme o peso molecular foram transferidas para uma membrana de nitrocelulose utilizando um sistema de transferência úmida por $60 \mathrm{~min}$ a 100 v com tampão de transferência pH 8,3 (Tris base, SDS, glicina e 20\% metanol). As membranas foram coradas com uma solução de Ponceau (Merck), para avaliar a eficiência da transferência e, em seguida, lavadas com água milli-Q.

As membranas foram incubadas por 1-2 $\mathrm{h}$ em uma solução (TBST+ $5 \%$ de BSA- bovine serum albumine) de bloqueio dos sítios inespecíficos. Em seguida, as membranas foram incubadas com o anticorpo primário, anti-Jun (1:1000), anti-JunB (1:500), anti-Fos (1:250), $\alpha$-actinina (1:1000), (Santa Cruz), diluídos em TBST e $5 \mathrm{mg}$ de BSA, overnight sob agitação, em câmara fria. Após esse período as membranas foram incubadas com 0 anticorpo secundário, anti-camundongo, anti-cabra ou anti-coelho por $1 \mathrm{~h}$, à temperatura ambiente sob agitação. Para revelação foi utilizado o Kit ECL-Plus (GE Healthcare) que utiliza como substrato o Luminol, que depois de degradado pela enzima do anticorpo secundário emite luz e impressiona uma chapa de raios $X$ (KODAK). Os filmes foram revelados, fixados, lavados e secos e as bandas das chapas de raios $X$ foram analisadas utilizando um sistema de captura de imagem Gene Snap 6.05 (SynGene-Synoptic Ltd) e quantificadas pelo programa Gene Tools 3.06 (SynGene-Synoptic). Os resultados foram apresentados na forma de gráficos. Foram realizados pelo menos três experimentos. 
4 RESULTADOS 


\subsection{ANÁlise dA EXPRESSÃo dOS GENES dA FAMílIA JUN E DO GENE FOS NAS CULTURAS DE CÉLULAS DE TUMORES ADRENOCORTICAIS}

A expressão dos genes da familia JUN, genes JUN, JUNB E JUND, e o gene FOS foi analisada por PCR array utilizando culturas de células de tumores adrenocorticais em relação à um pool de adrenais normais. Esses resultados foram apresentados em clustergrama na Figura 1. Nessa figura está representada a relação entre as culturas estudadas e a expressão dos genes da familia JUN e do gene FOS através da diferença na intensidade de cor. Quanto mais verde menor é o nível de expressão dos genes analisados e quanto mais vermelho maior esse nível. Podemos portanto observar que, em relação ao pool de adrenais normais, as culturas de tumores adrenocorticais estudadas apresentaram baixos níveis de expressão dos genes da familia JUN e FOS. Dentre os genes da familia Jun, aqueles com os nívies de expressão maior foram os genes os genes JUN e JUND, enquanto os genes Fos e JunB, são os que apresentaram os menores níveis.

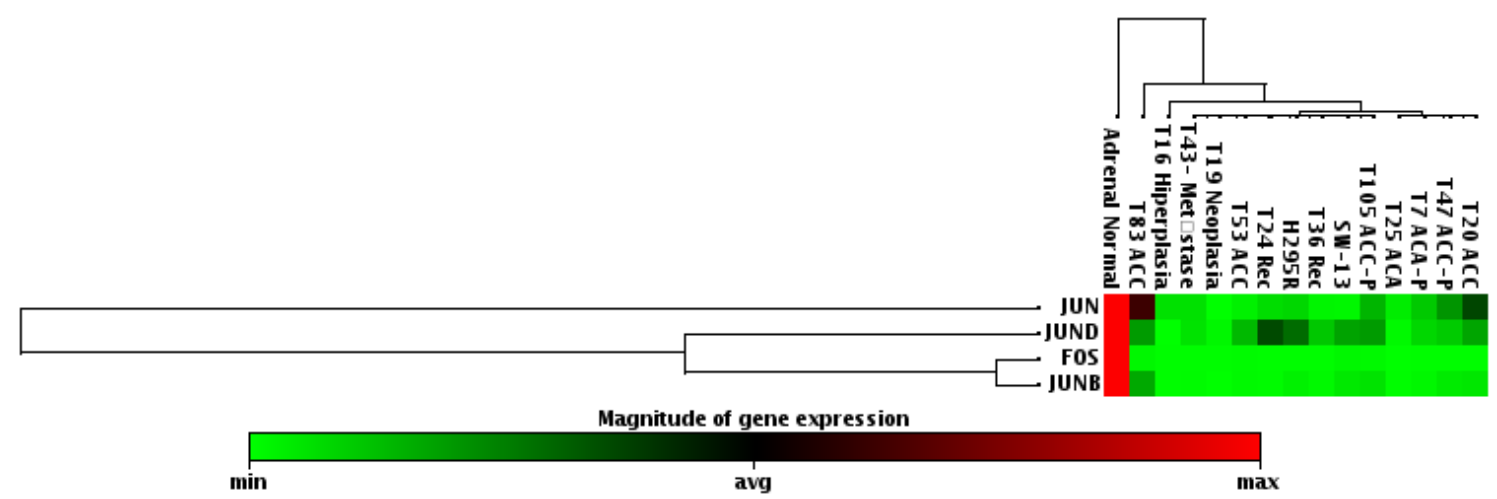

Figura 5.Clustergrama da expressão dos genes da família JUN e do gene FOS nas culturas de células de tumores adrenocorticais. Diferenças na intensidade de cor determinam a intensidade da expressão, verde (menor expressão) e vermelho (maior expressão).

Na Figura 6 estão apresentados os resultados da expressão relativa do gene JUN nas diferentes culturas, linhagens e culturas secundárias de tumores adrenocorticais, tendo o pool de adrenais normais como calibrador (1.0 fold change). Dentre as culturas analisadas somente as culturas de células dos carcinomas adultos, as células T83, T20, apresentaram uma maior expressão de JUN. No entanto, as linhagens e a T53, também carcinomas, apresentaram níveis de expressão muito baixos. As culturas de células pediátricas, T7, T47 e T105 apresentaram níveis de expressão semelhantes de JUN, independente se carcinomas ou adenomas. 


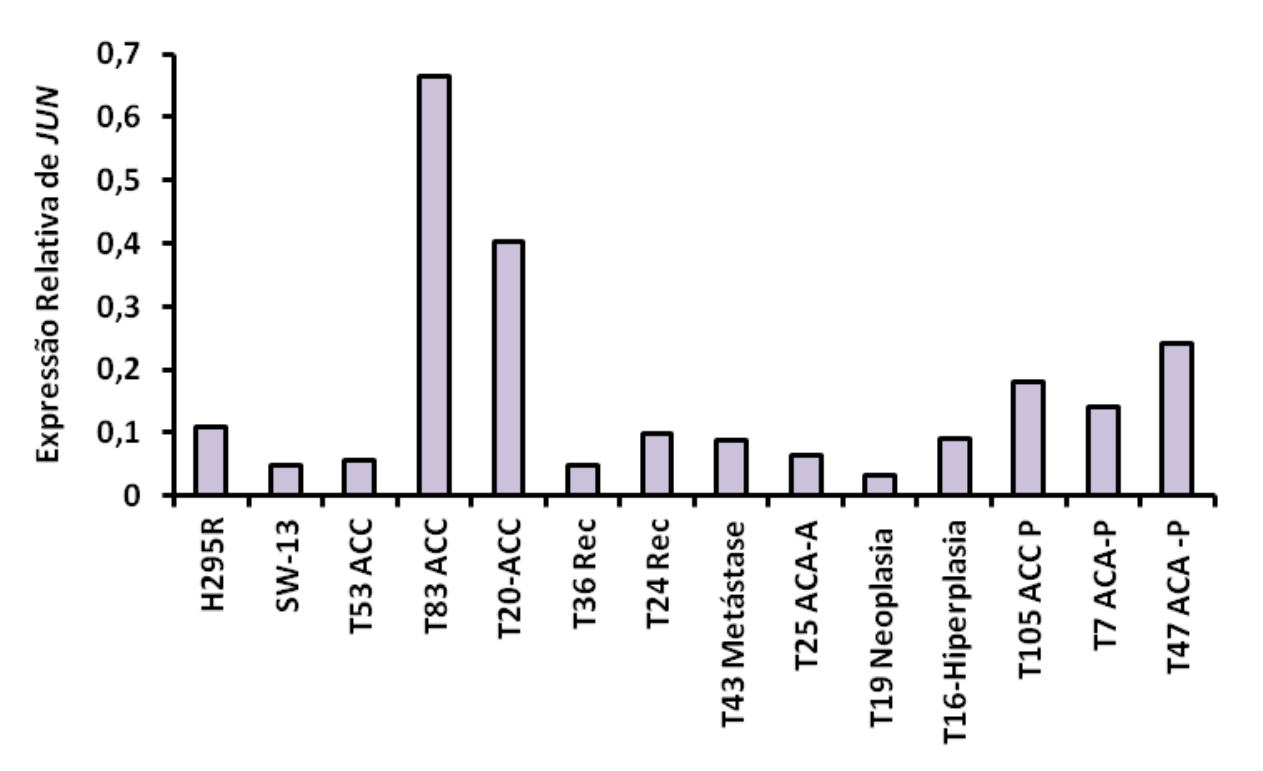

Figura 6 Análise comparativa da expressão do gene JUN em culturas de células de linhagens adrenocorticais adultas (H295R e SW-13), adenomas (ACA) e carcinomas adrenocorticais (ACC) pediátricos (P) e adultos (A), duas recidivas de carcinoma (Rec), uma metástase, uma hiperplasia e uma neoplasia que foram comparados ao pool de tecido de adrenais normais. $\mathrm{n}=1$.

A análise da expressão do gene JUNB (Figura 7), mostrou um padrão semelhante de expressão quando comparado com gene JUN, mas com um nível de expressão ainda mais baixo em relação ao pool de adrenais normais. Enquanto a expressão de JUNB na células do carcinoma T83 foi relativamente maior dentre as culturas estudadas, os demais carcinomas, apesar de uma expressão muito baixa, foram semelhantes às linhagens H295R e SW-13, que são também provenientes de carcinomas. 


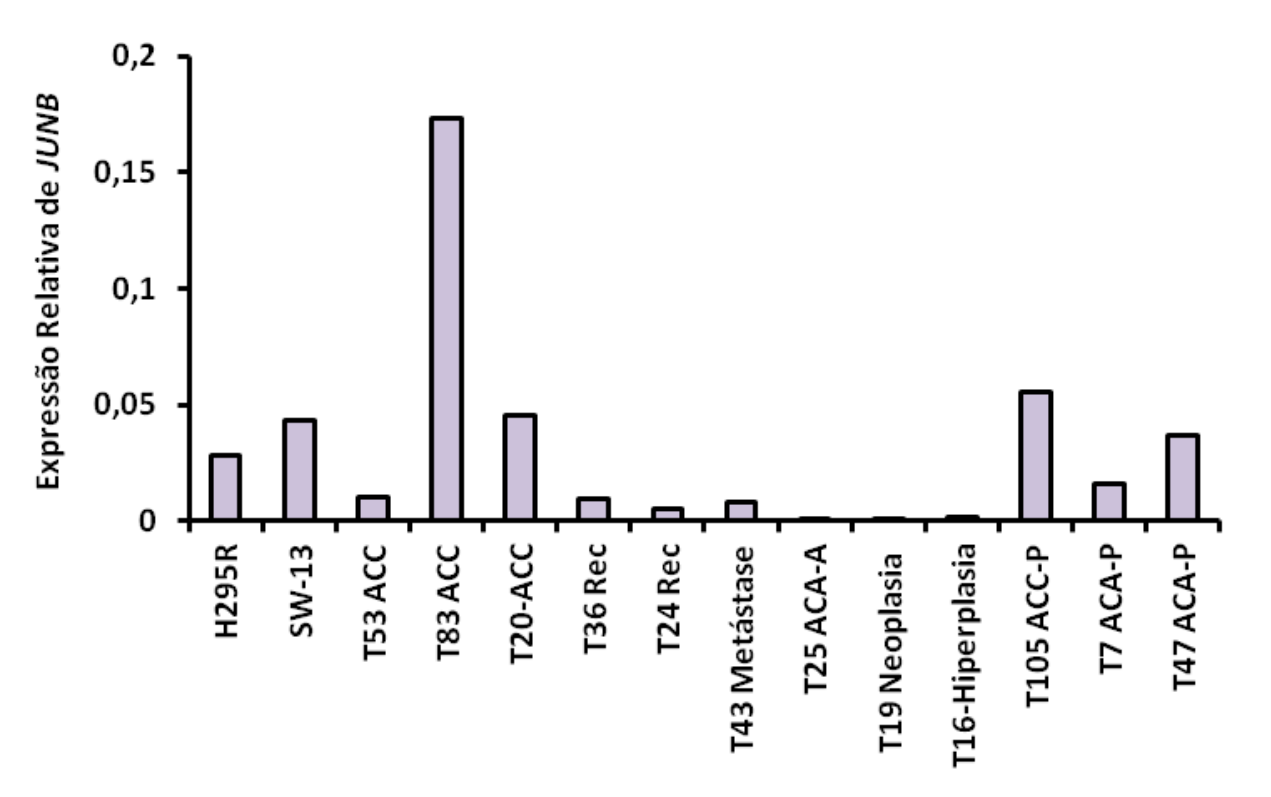

Figura 7.Análise comparativa da expressão do gene JUNB em culturas de células de linhagens adrenocorticais adultas (H295R e SW-13), adenomas (ACA) e carcinomas adrenocorticais (ACC) pediátricos (P) e adultos (A), duas recidivas de carcinoma (Rec), uma metástase, uma hiperplasia e uma neoplasia que foram comparados ao pool de tecido de adrenais normais. $n=1$

A expressão do gene JUND foi similar entre os carcinomas e recidivas, enquanto nas culturas de células da metastase, neoplasia e hiperplasia, esse gene, praticamente, não está expresso em relação à adrenal normal.

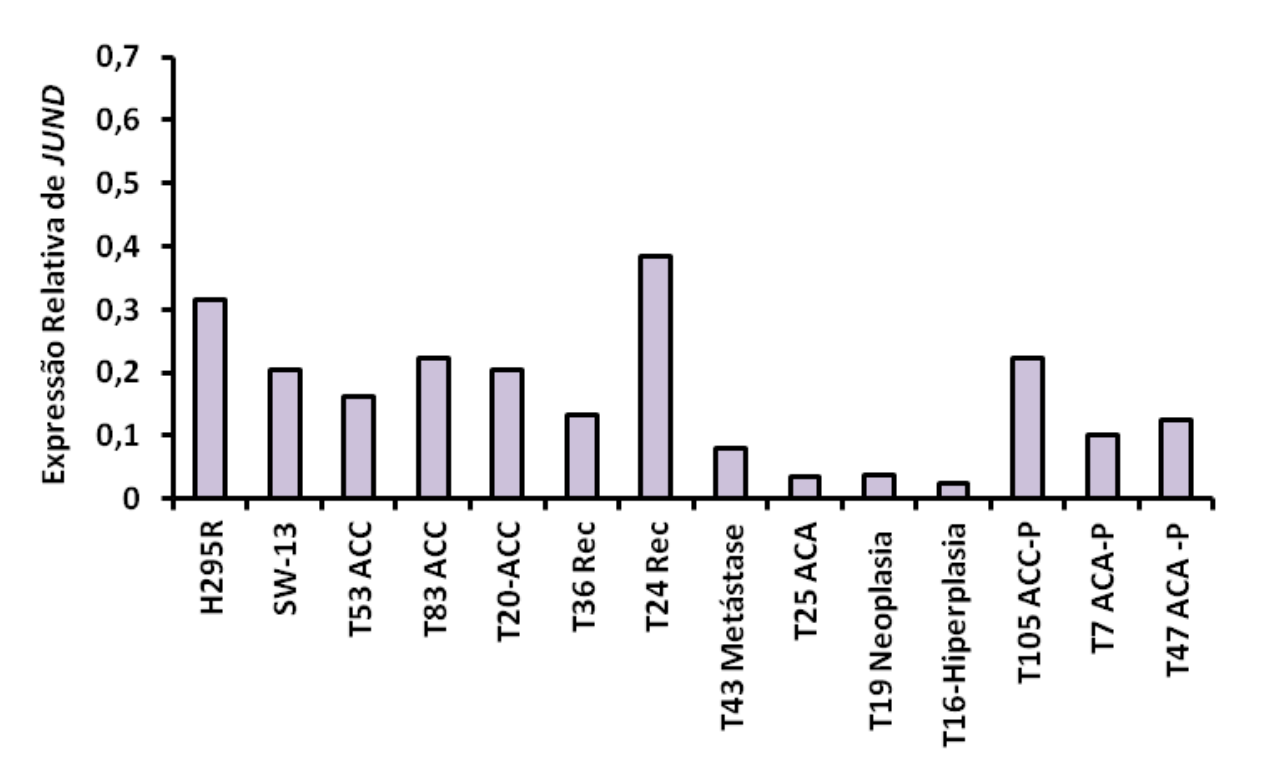

Figura 8.Análise comparativa da expressão do gene JUND em culturas de células de linhagens adrenocorticais adultas (H295R e SW-13), adenomas (ACA) e carcinomas adrenocorticais (ACC) pediátricos (P) e adultos (A), duas recidivas de carcinoma (Rec), uma metástase, uma hiperplasia e uma neoplasia que foram comparados ao pool de tecido de adrenais normais. $n=1$ 
Dentre os genes analisados, o gene FOS é o de mais baixa expressão, sendo inferior a $20 \%$ da expressão em relação ao pool de adrenais normais.

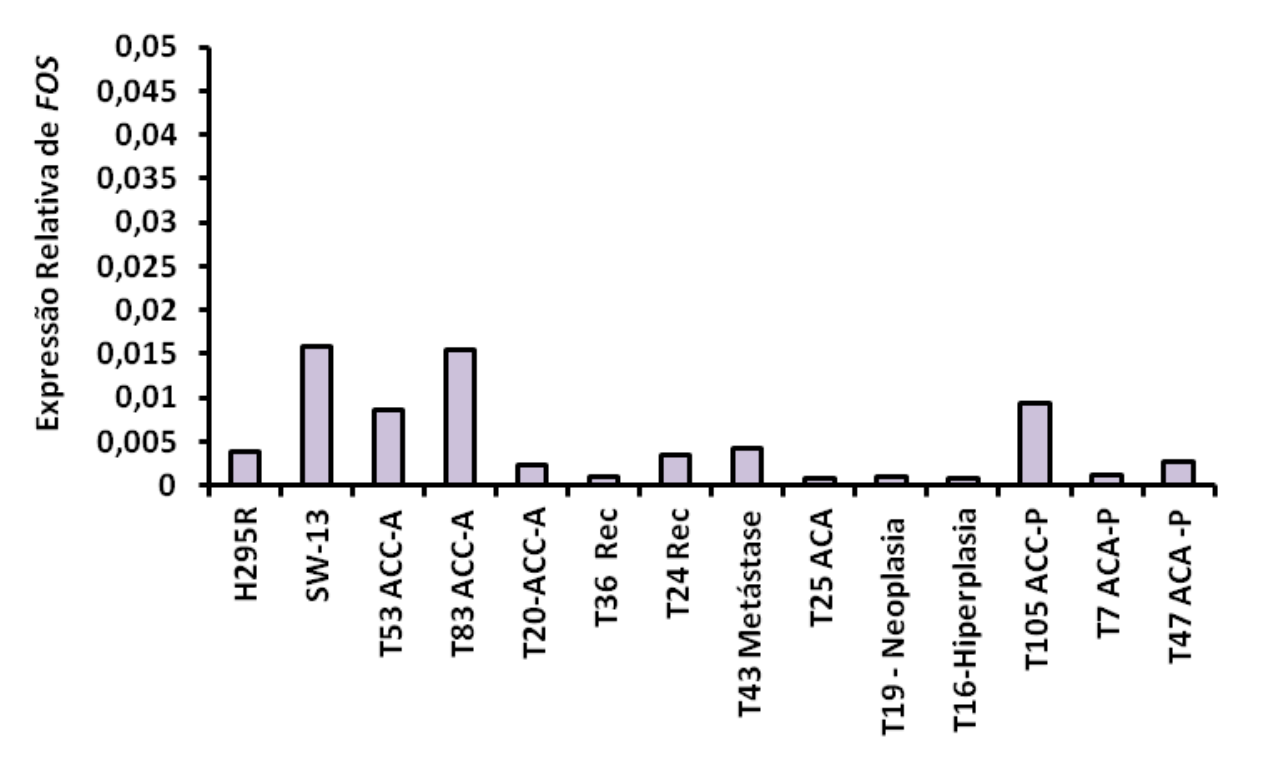

Figura 9 Análise comparativa da expressão do gene FOS em culturas de células de linhagens adrenocorticais adultas (H295R e SW-13), adenomas (ACA) e carcinomas adrenocorticais (ACC) pediátricos $(P)$ e adultos $(A)$, duas recidivas de carcinoma (Rec), uma metástase, uma hiperplasia e uma neoplasia que foram comparados ao pool de tecido de adrenais normais. $\mathrm{n}=1$

\subsection{VALIDAÇÃO DA EXPRESSÃo dOS GENES DA FAMILIA JUN E DO GENE FOS POR PCR QUANTITATIVO}

Para validar os dados obtidos por PCR Array, foi realizado o PCR quantitativo em tempo real. As culturas utilizadas foram selecionadas a partir dos resultados obtidos nas análises por PCR array. Foram analisadas as culturas de células das recidivas de carcinoma adrenocortical adulto, culturas T24 e T36, dois adenomas adrenocorticais, as culturas de células T25 e a T7 e as culturas de células de origem pediátrica. Como calibrador e controle, foi utilizado o pool de adrenais normais e como controle endógeno o gene $\beta$ Actina. Os resultados da expressão do gene JUN e JUNB nas diferentes culturas analisadas e apresentados nas Figuras 6 e 7, foram estatisticamente signficantes $(p<0.001)$ e mostram uma baixa expressão desses genes em relação ao pool de adrenais normais. 


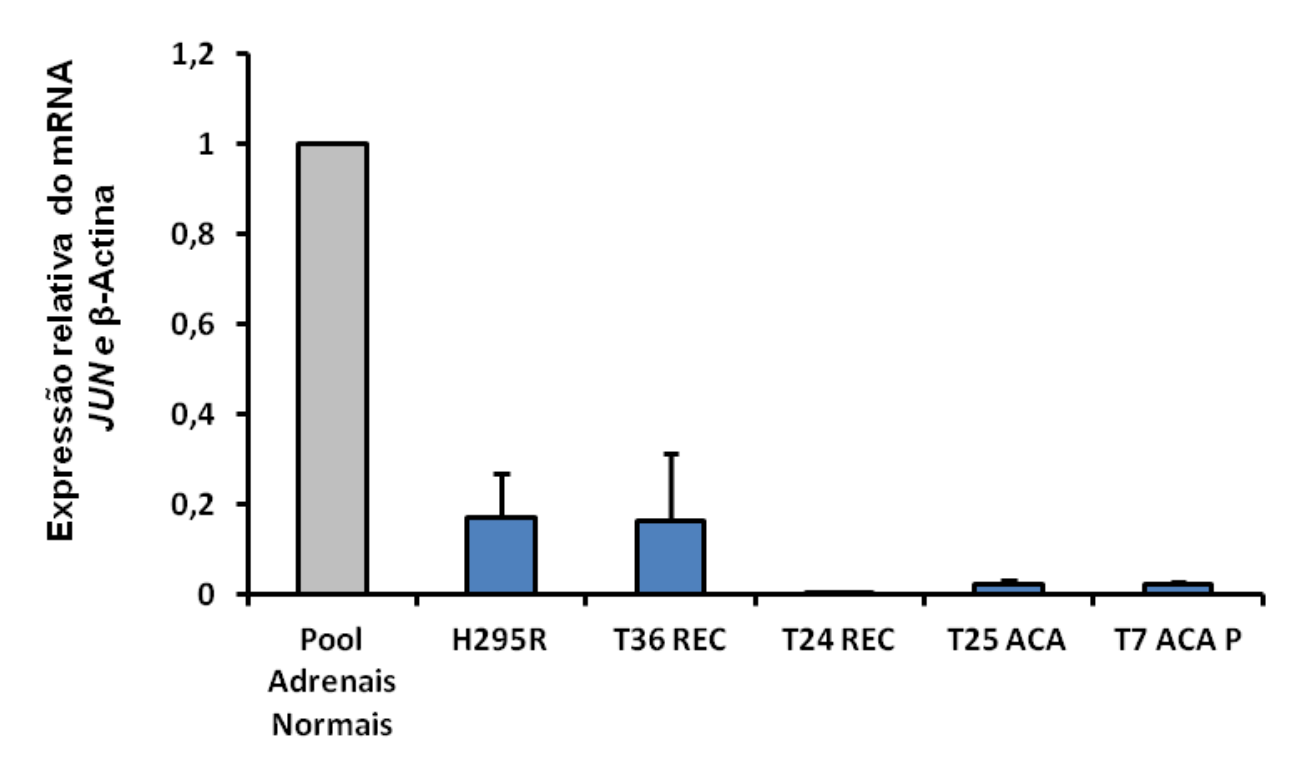

Figura 10. Análise da expressão gênica de $J U N$ por qPCR, nas células das recidivas de carcinomas adrenocorticais adultos T24 e T36 e nas células das culturas de adenomas adrenocorticais pediátrico (T7) e adulto (T25). O pool de adrenais normais foi utilizada como calibrador e controle, a $\beta$-Actina foi utilizada como controle endógeno. Análise estatística por teste ANOVA $p<0.001 . n=3$.

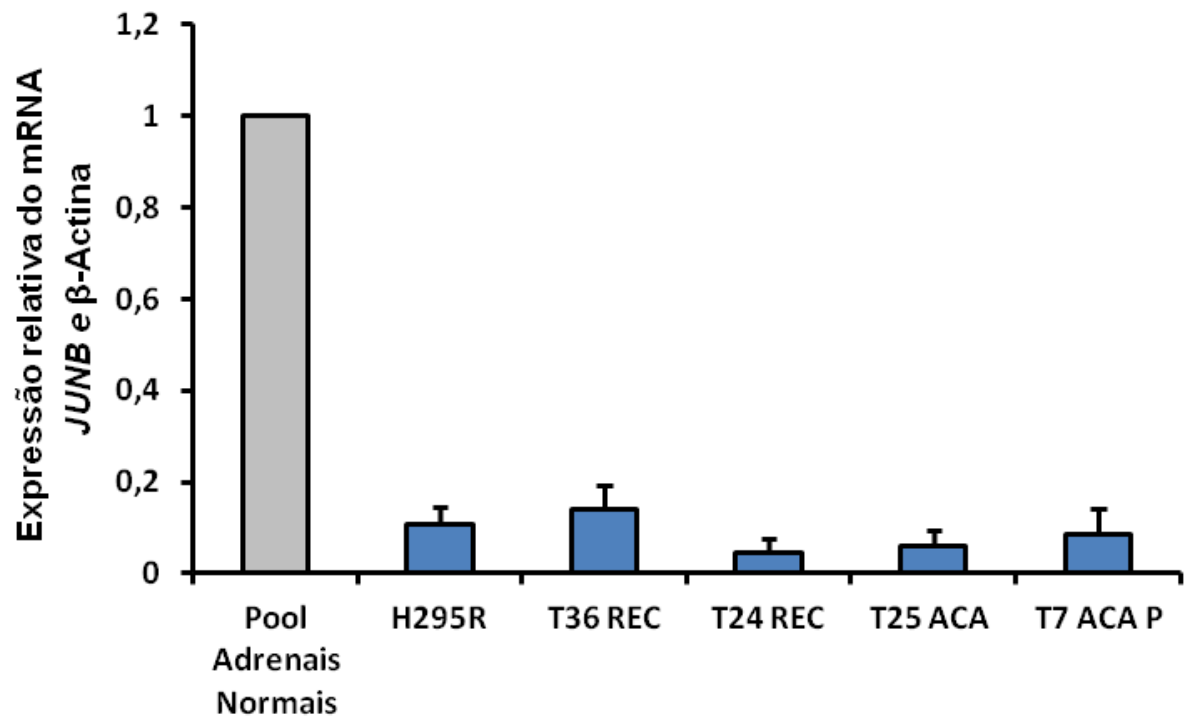

Figura 11. Análise da expressão gênica de JUNB por qPCR, nas células das recidivas de carcinomas adrenocorticais adultos T24 e T36 e nas células das culturas de adenomas adrenocorticais pediátrico (T7) e adulto (T25). O pool de adrenais normais foi utilizada como calibrador e controle, a $\beta$-Actina foi utilizada como controle endógeno. Análise estatística por teste ANOVA $p<0.001 . n=3$.

Dentre os genes validados por PCR quantitativo, a expressão relativa do gene JUND (Figura 8) foi a que apresentou maiores diferenças de expressão entre as culturas de células analisadas. Enquanto a linhagem H295R e a recidiva de tumor, cultura T36 não apresentaram diferenças estatisticas em relação à adrenal normal, a outra cultura de uma recidiva de tumor, as células 
T24 e os adenomas de adulto e pediátrico, apresentaram baixa expressão de JUND.

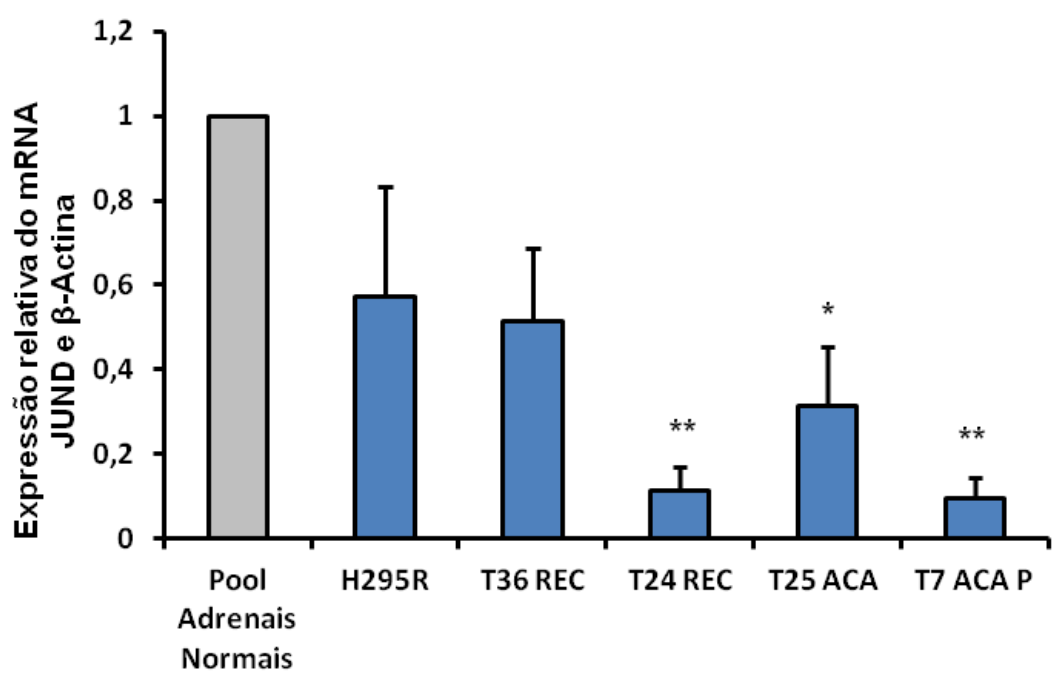

Figura 12. Análise da expressão gênica de JUND por qPCR, nas células das recidivas de carcinomas adrenocorticais adultos T24 e T36 e nas células das culturas de adenomas adrenocorticais pediátrico (T7) e adulto (T25). O pool de adrenais normais foi utilizada como calibrador e controle, a $\beta$-Actina foi utilizada como controle endógeno. Análise estatística por teste ANOVA ${ }^{* *} p<0.01 e^{*} p<0.05 . n=3$.

O gene FOS, a exemplo dos genes da familia JUN, foi igualmente pouco expresso nas culturas de células analisadas (Figura 8).

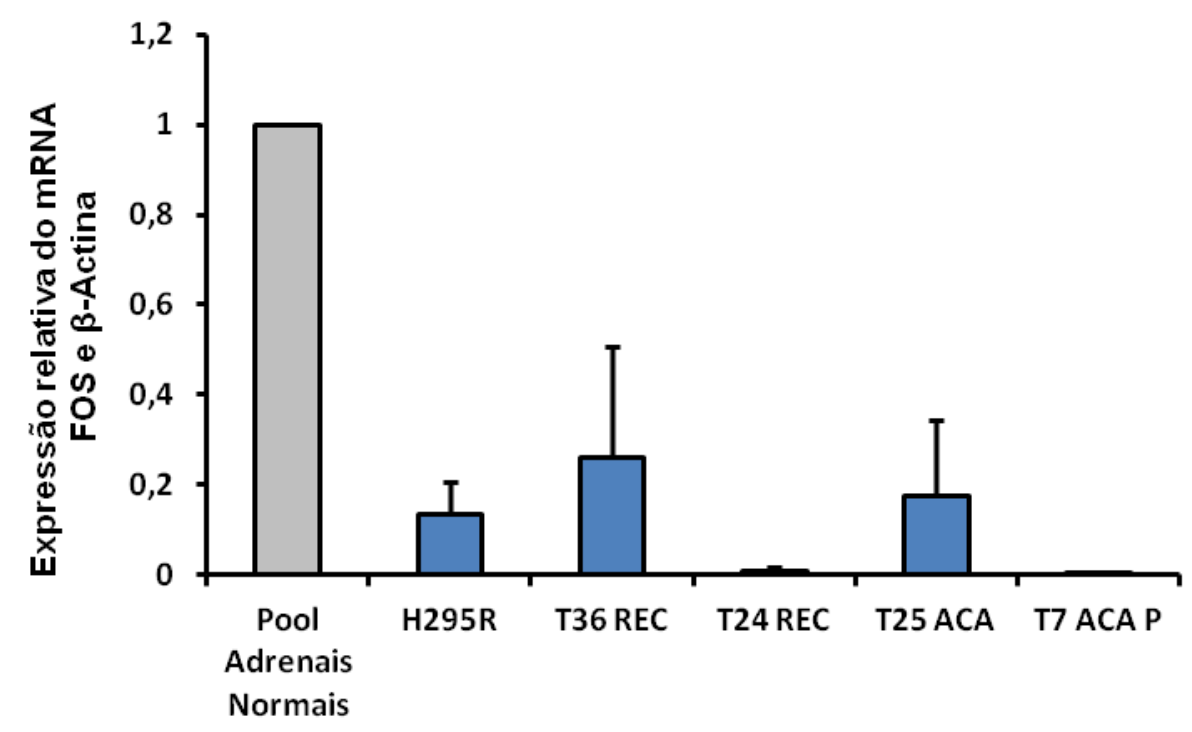

Figura 13.Análise da expressão gênica de FOS por qPCR, nas células das recidivas de carcinomas adrenocorticais adultos T24 e T36 e nas células das culturas de adenomas adrenocorticais pediátrico (T7) e adulto (T25). O pool de adrenais normais foi utilizada como calibrador e controle, a $\beta$-Actina foi utilizada como controle endógeno. Análise estatística por teste ANOVA $p<0.001 . n=3$. 


\subsection{ANÁLISE DA EXPRESSÃo DOS GENES DA FAMILIA JUN E DO GENE FOS APÓS ESTÍMULO COM ACTH E FORSKOLINA EM CÉLULAS DE TUMORES ADRENOCORTICAIS}

Como descrito anteriormente, os genes da familia JUN e o gene FOS, por serem genes de resposta primaria são modulados por hormonios e fatores de crescimento (Scheer, 1994). Portanto, devido à baixa expressão dos genes que foram estudados nas culturas de células dos tumores adrenocorticais, analisamos a capacidade desse genes de responderem, in vitro, à ação de hormônios como o ACTH, e ao fator ativador da via PKA, a Forskolina. Foi mantida como calibrador a linhagem H295R e como controle endógeno o gene da $\beta$-actina. Após o estímulo com $10^{-7} \mathrm{M}$ ACTH e $10^{-9} \mathrm{M}$ Forkolina somente a linhagem H295R apresentou um aumento signicante da expressão de JUN (Figura 10; $p<0.05$ ). Por outro lado, tanto a linhagem H295R quanto a cultura de células T36-Rec (Figura 11) apresentaram um aumento estatisticamente significante respectivamente, $\mathrm{p}<0.01$ e $\mathrm{p}<0.05$, da expressão de $J U N B$, após estímulo com ACTH. Além disso, a linhagem H295R apresentou aumento da expressão de JUNB após o estímulo com Forskolina.

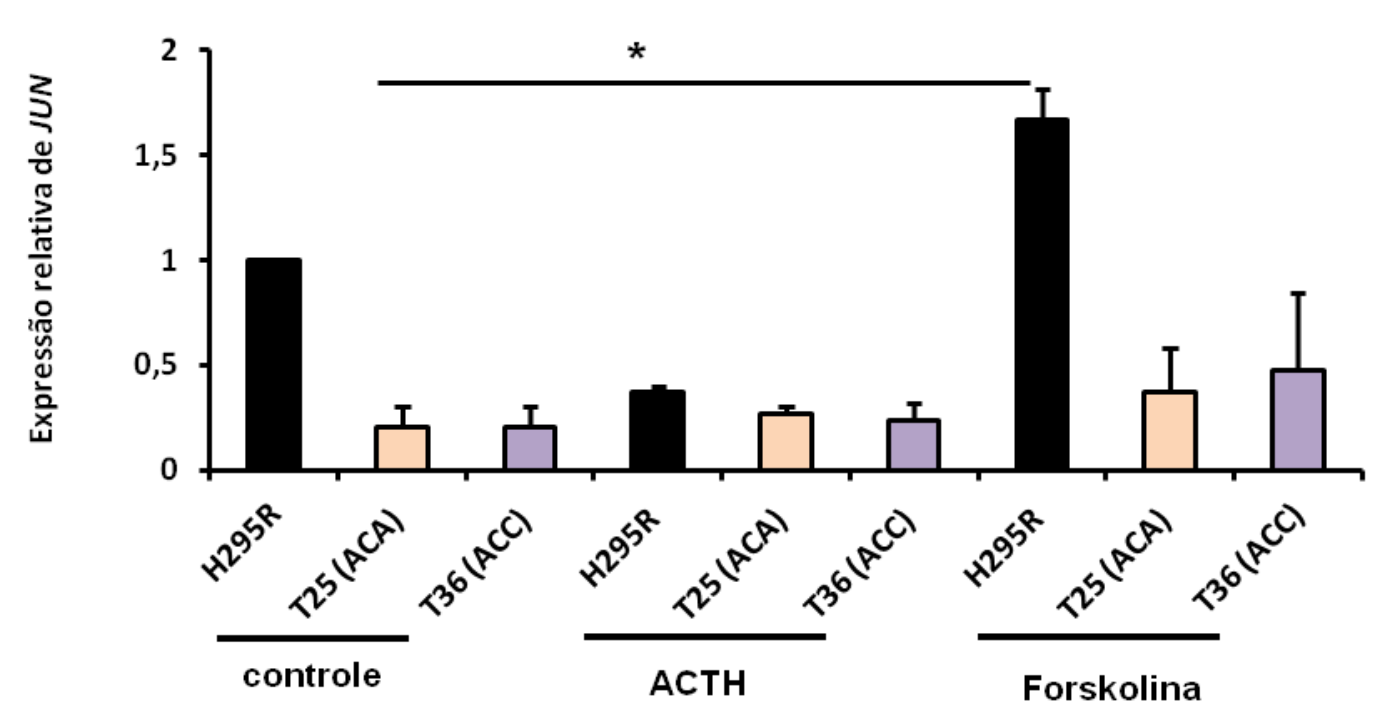

Figura 14.Análise da expressão gênica de JUN em tumores adrenocorticais adultos, sendo uma recidiva (cultura T36- barra lilás) e um adenoma (cultura T25- barra rosa) após estímulo por ACTH $10^{-7} \mathrm{M}$ e Forskolina $10^{-9} \mathrm{M}$. A amostra calibradora foi H295R (barra preta) sem tratamento. Análise estatística por teste ANOVA * $p<0.05 . n=3$. 


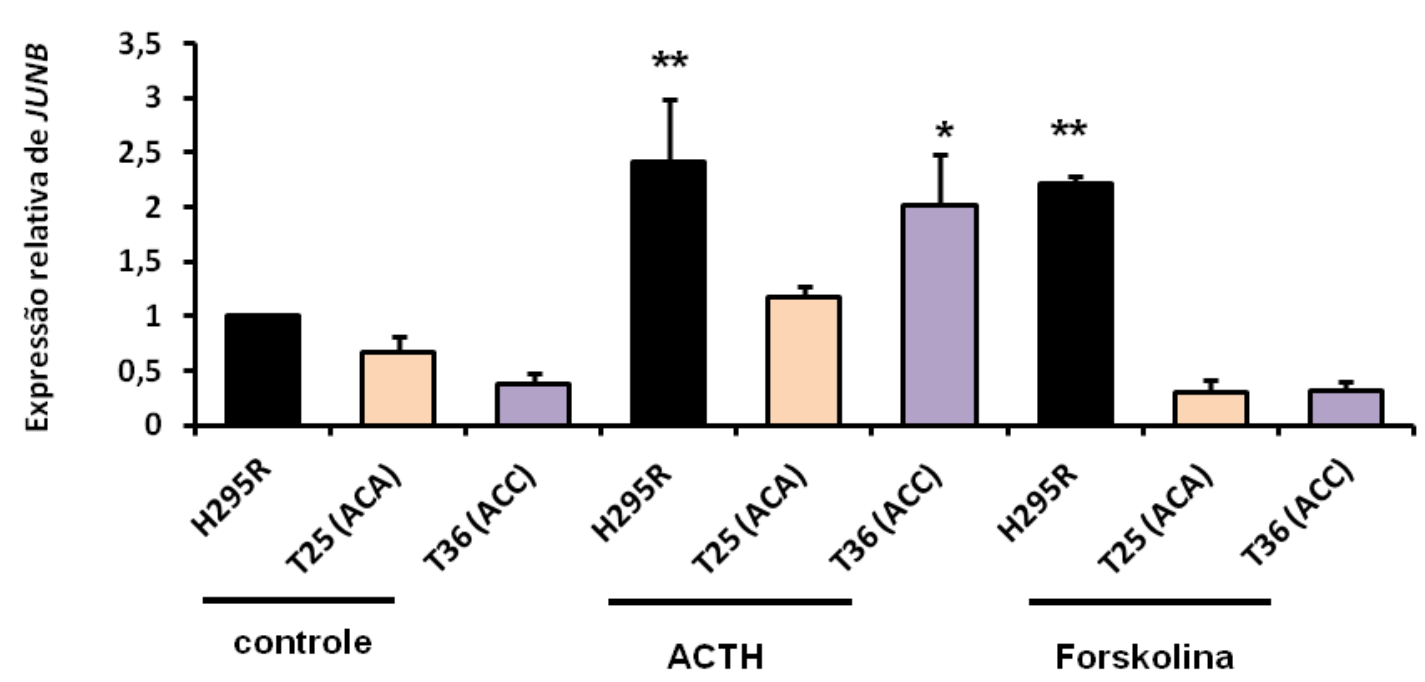

Figura 15 Análise da expressão gênica de JUNB em tumores adrenocorticais adultos, sendo uma recidiva (cultura T36- barra lilás) e um adenoma (cultura T25- barra rosa) após estímulo por ACTH $10^{-7} \mathrm{M}$ e Forskolina $10^{-9} \mathrm{M}$. A amostra calibradora foi H295R (barra preta) sem tratamento. Análise estatística por teste ANOVA ${ }^{*} P<0.05$ e ${ }^{* *} P<0.01$. $n=3$.

Os resultados da expressão do gene JUND (Figura 12) mostraram que a cultura de células do adenoma, células T25-ACA, apresentou esse gene menos expresso em relacão à linhagem H295R ( $p<0.05)$, e que a ação do ACTH diminui sua expressão. Com relação ao gene FOS (Figura 13), tanto a cultura de carcinoma quanto de adenoma apresentaram, em relação à linhagem H295R, uma baixa expressão de FOS. A cultura de células T25-ACA, apresentou um aumento siginficante $(p<0.05)$ após tratamento com $A C T H$. 


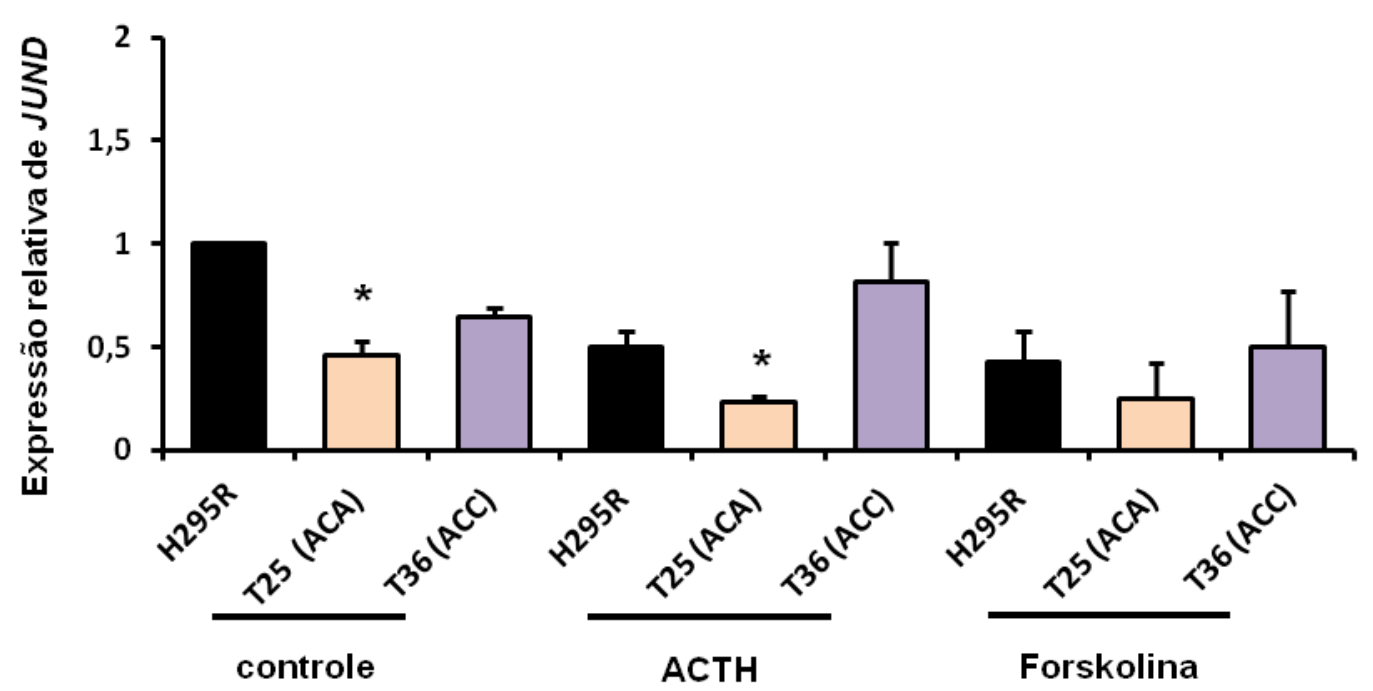

Figura 16.Análise da expressão gênica de JUND em tumores adrenocorticais adultos, sendo uma recidiva (cultura T36- barra lilás) e um adenoma (cultura T25- barra rosa) após estímulo por ACTH $10^{-7} \mathrm{M}$ e Forskolina $10^{-9} \mathrm{M}$. A amostra calibradora foi H295R (barra preta) sem tratamento. Análise estatística por teste ANOVA * $p<0.05 . n=3$.

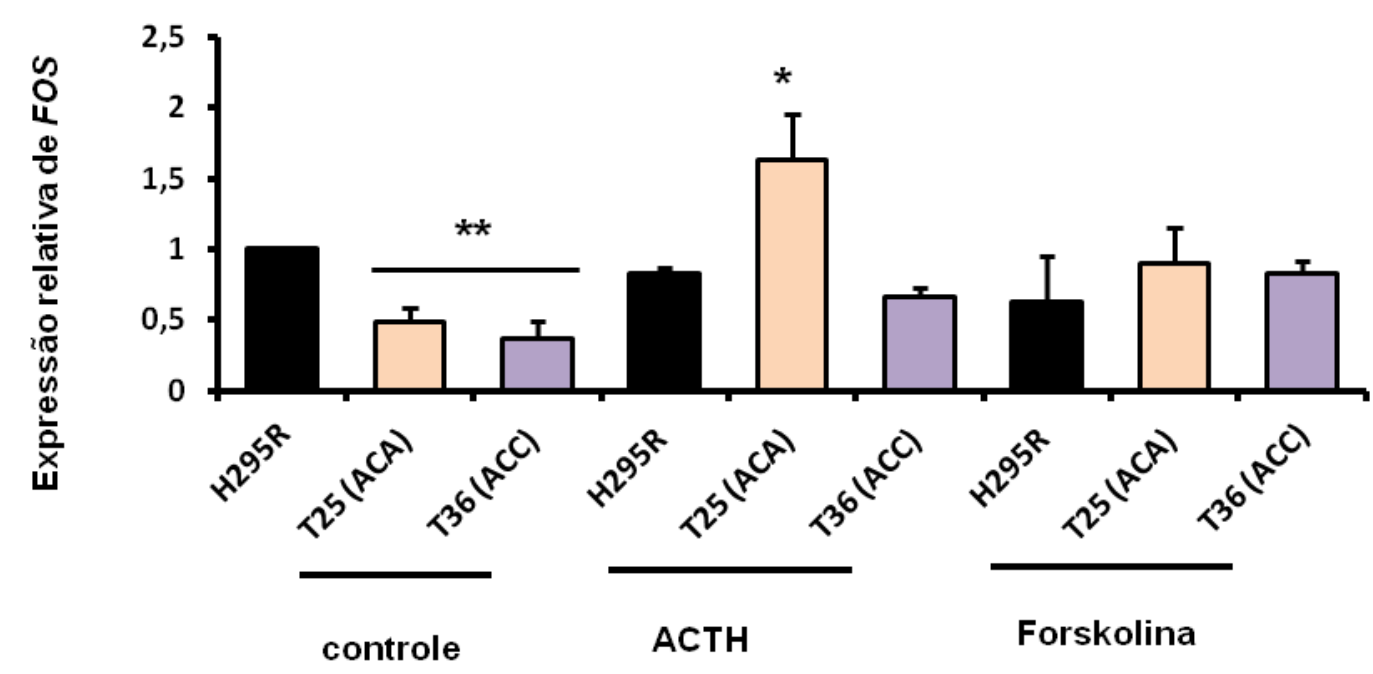

Figura 17.Análise da expressão gênica de FOS em tumores adrenocorticais adultos, sendo uma recidiva (cultura T36- barra lilás) e um adenoma (cultura T25- barra rosa) após estímulo por ACTH $10^{-7} \mathrm{M}$ e Forskolina $10^{-9} \mathrm{M}$. A amostra calibradora foi H295R (barra preta) sem tratamento. Análise estatística por teste ANOVA $p<0.001 .{ }^{*} P<0.05 e^{\star \star} P<0.01 . n=3$. 


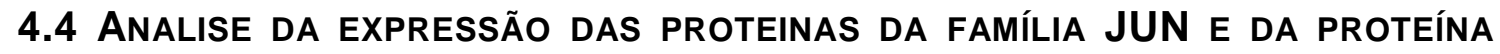 FOS NAS CULTURAS DAS CÉLULAS ADRENOCORTICAIS}

A análise da expressão da proteína JUN nas células da linhagem H295R (Figura 18) e das células T36 de uma recidiva de carcinomas (Figura 19) mostrou que, ambas as culturas apresentam uma expressão basal de JUN quando crescendo exponencialmente. Após tratamento com $10^{-9} \mathrm{M} \mathrm{ACTH} \mathrm{e} 10^{-}$ ${ }^{7} \mathrm{M}$ Forskolina (FK), ambas as culturas apresentaram aumento da expressão de JUN, que na linhagem H295R foi significante, respectivamente $p=0.0008$ e $\mathrm{p}=0.0101$ para $\mathrm{ACTH}$ e FK.
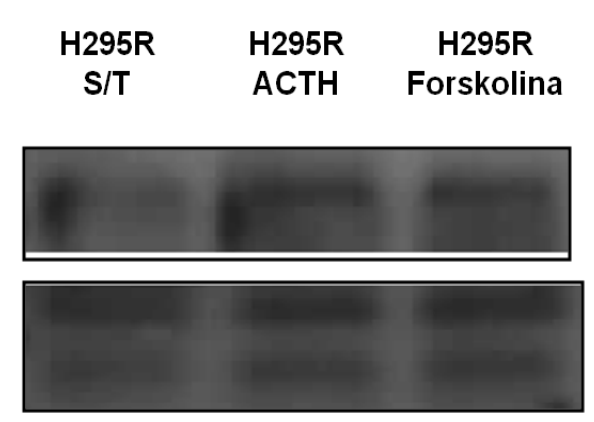

a-Actinina

JUN

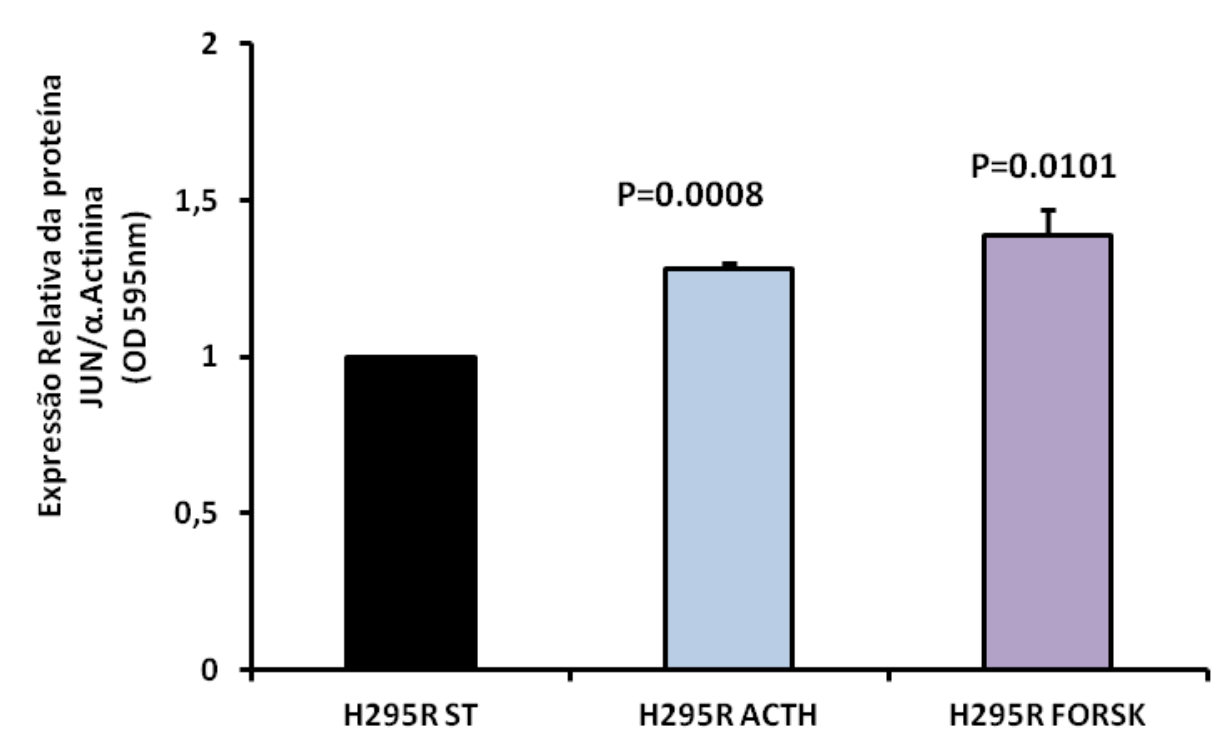

Figura 18. Expressão da proteína JUN nas células das culturas de tumores adrenocorticais tratadas com $10^{-9} \mathrm{M}$ ACTH e $10^{-7} \mathrm{M}$ Forskolina.Como controle foram utilizadas células da linhagem H295R sem tratamento (ST). Análise estatística por teste $T p=0.0008$ e $\mathrm{p}=0.0101$. $n=3$. 


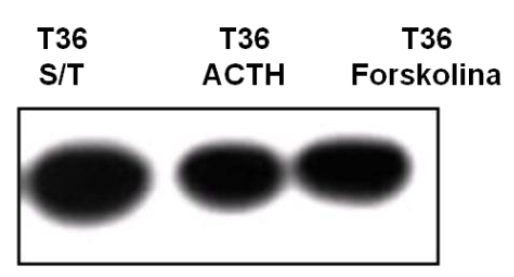

a-Actinina

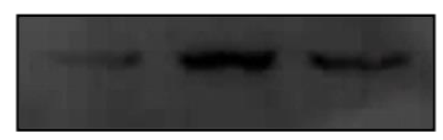

JUN

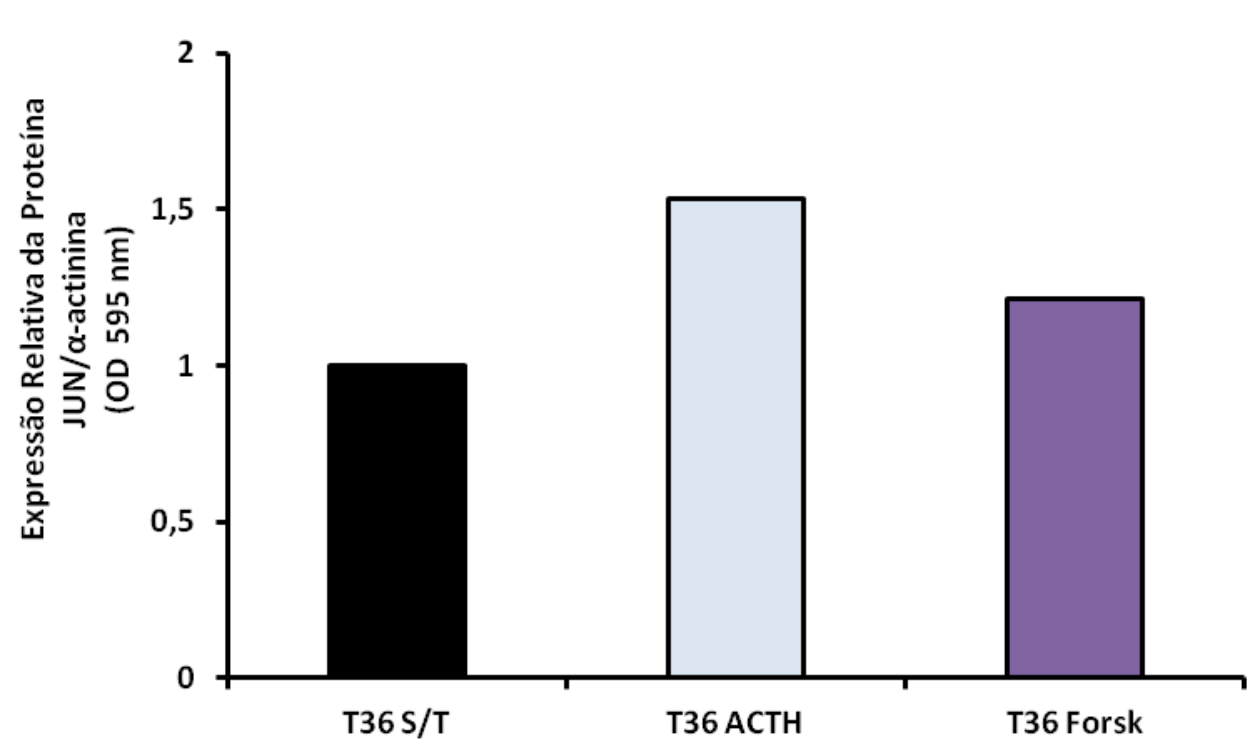

Figura 19. Expressão da proteína JUN nas células das culturas de tumores adrenocorticais tratadas com $10^{-9} \mathrm{M}$ ACTH e $10^{-7} \mathrm{M}$ Forskolina. Como controle foram utilizadas células da cultura de recidiva de carcinoma T36 sem tratamento (ST). $n=1$

A exemplo do observado na expressão da proteína JUN, as células H295R após estimulo com FK mas não com ACTH, apresentaram um aumento siginficante $(\mathrm{p}=0.0099)$ de JUNB (Figura 20), o que corrobora parcialmente 0 que foi observado em qPCR (Figura 15). Por qPCR o gene JUNB, após ambos tratamentos apresenta um aumento siginficante de expressão. Por outro lado, a expressão da proteina JUNB nas células T36 (Figura 21), que apresenta um basal de expressão alto quando crescendo exponencialmente, quando tratadas com ACTH estão de acordo com o aumento observado em qPCR, isto é, ACTH promove um aumento da expressão de JUNB. Por outro lado, a FK inibe a expressão dessa proteina. Esses resultados sugerem que a estimulação de JUNB na cultura de células T36 ocorre através de uma via diferente da da via CAMP/PKA. 


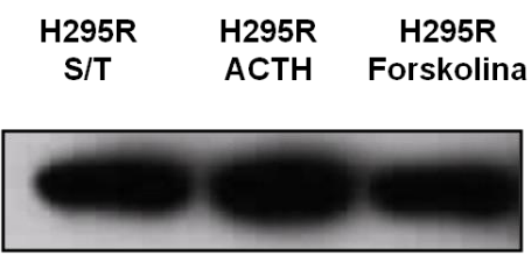

$\alpha-A c t i n i n a$

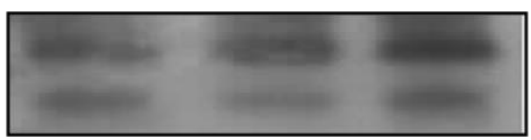

JUNB

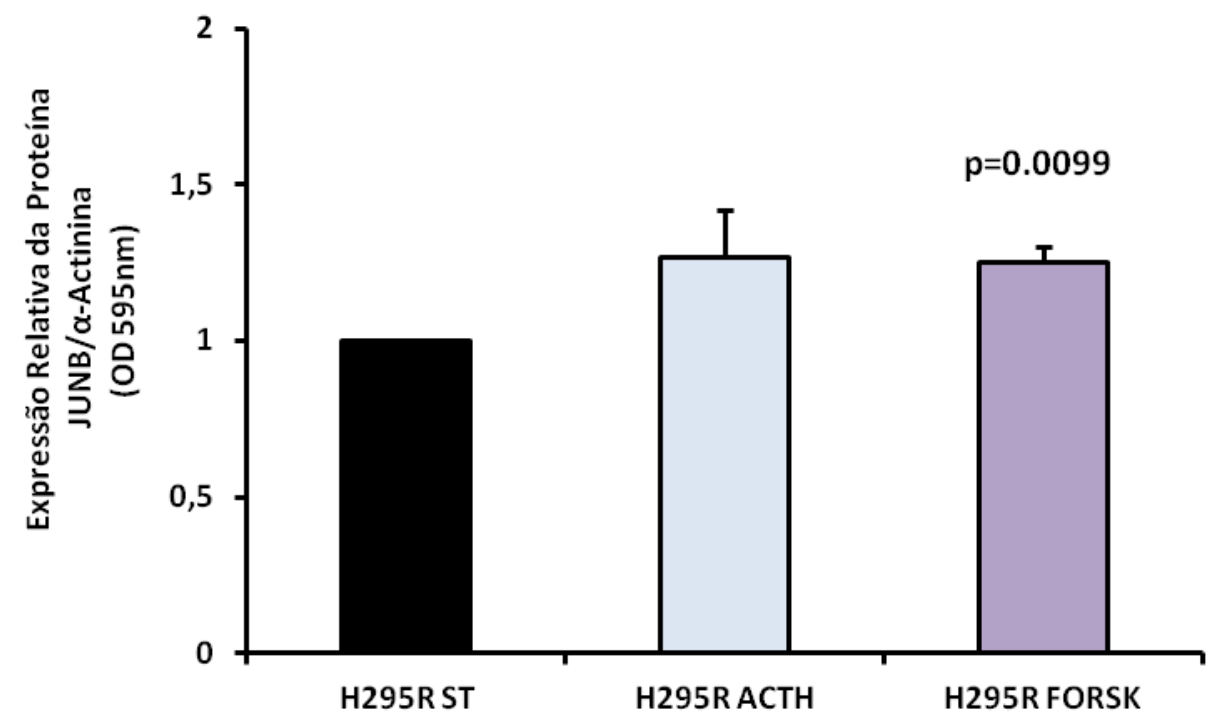

Figura 20.Expressão da proteína JUNB nas células das culturas de tumores adrenocorticais tratadas com $10^{-9} \mathrm{M}$ ACTH e $10^{-7} \mathrm{M}$ Forskolina.Como controle foram utilizadas células da linhagem H295R sem tratamento (ST). Análise estatística por teste $T p=0.0099$. $n=3$. 

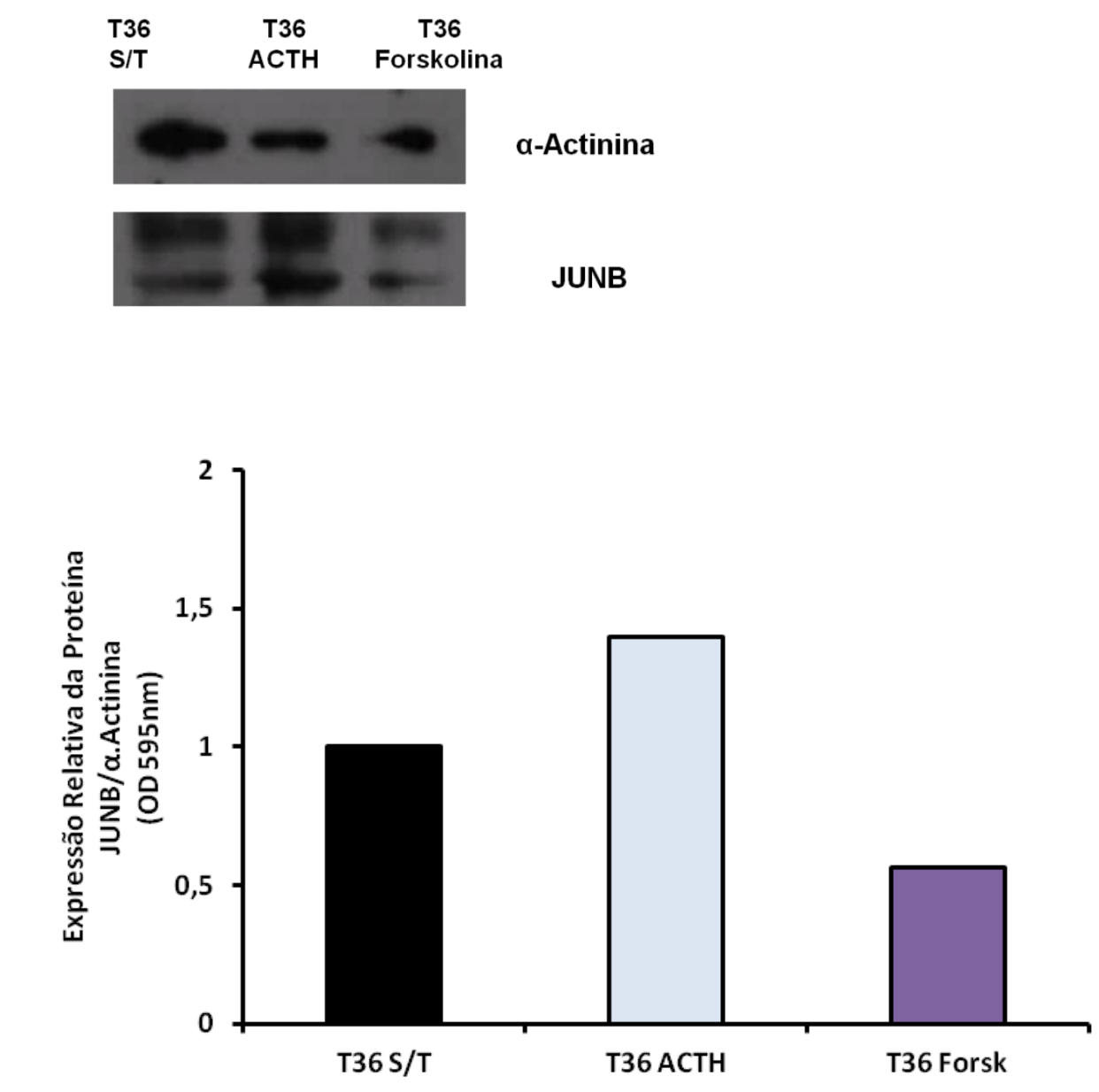

Figura 21. Expressão da proteína JUNB nas células das culturas de tumores adrenocorticais tratadas com $10^{-9} \mathrm{M}$ ACTH e $10^{-7} \mathrm{M}$ Forskolina.Como controle foram utilizadas células da cultura de recidiva de carcinoma T36 sem tratamento (ST).

Em relação à expressão da proteína JUND, que em ambas as células apresenta expressão basal dessa proteina, as células da linhagem H295R (Figura 22) apresentaram um aumento significante dessa proteina após tratamento com ACTH ( $p=0.0053$ ), enquanto com FK a diminuição observada de JUND não foi siginificante, pois houve grande variação entre experimentosNo caso da proteina JUND, as duas isoformas observadas ocorrem provavelmente devido à um inicio interno na tradução da proteina (informações obtidas do fabricante do anticorpo). Nas células da cultura T36 (Figura 23), as isoformas mais leves estão menos expressas e os dois tratamentos aumentam os níveis dessa proteina. 

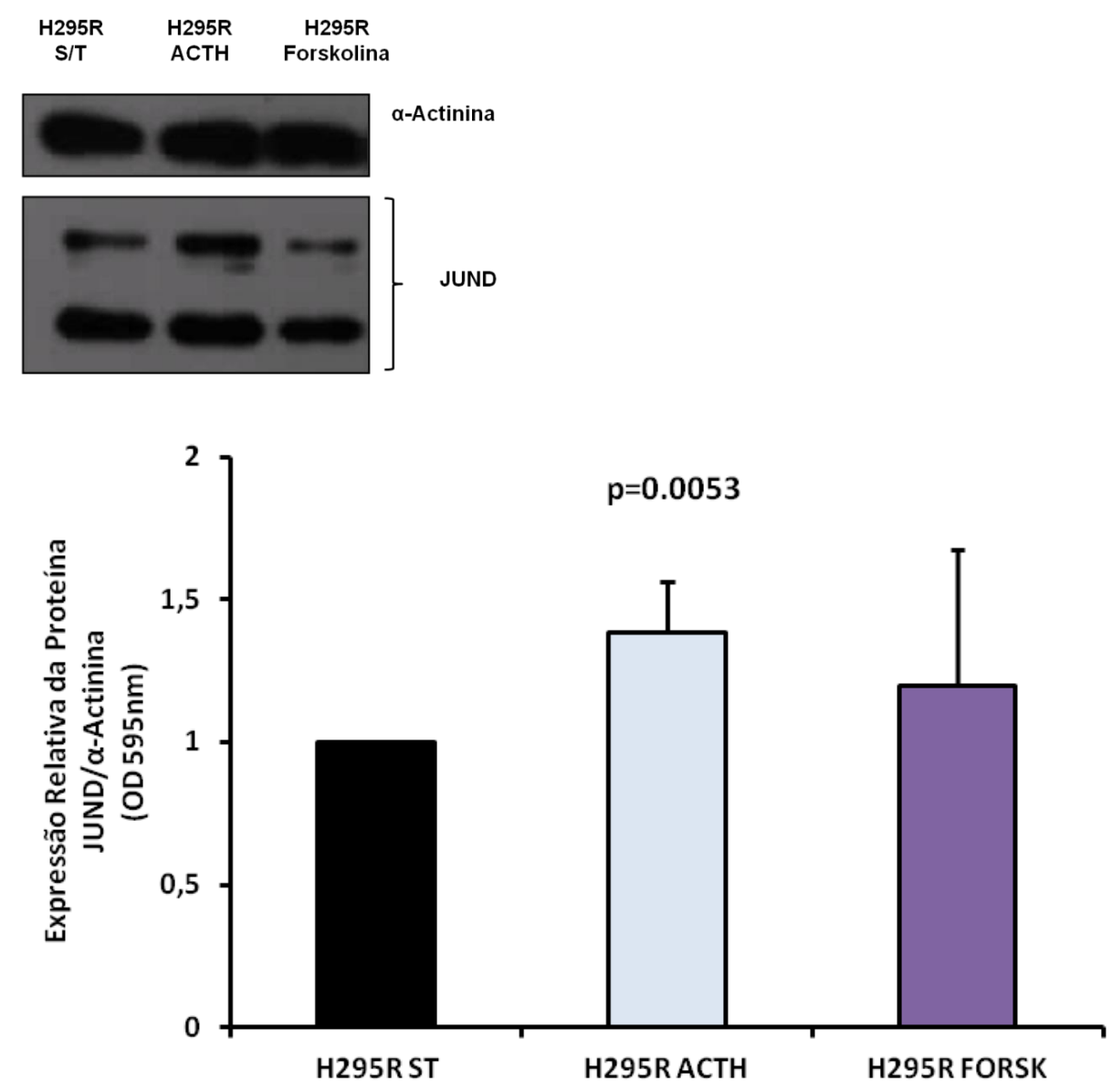

Figura 22.Expressão da proteína JUND nas células das culturas de tumores adrenocorticais tratadas com $10^{-9} \mathrm{M}$ ACTH e $10^{-7} \mathrm{M}$ Forskolina.Como controle foram utilizadas células da linhagem H295R sem tratamento (ST). Análise estatística por teste T $p=0.0053 n=3$. 

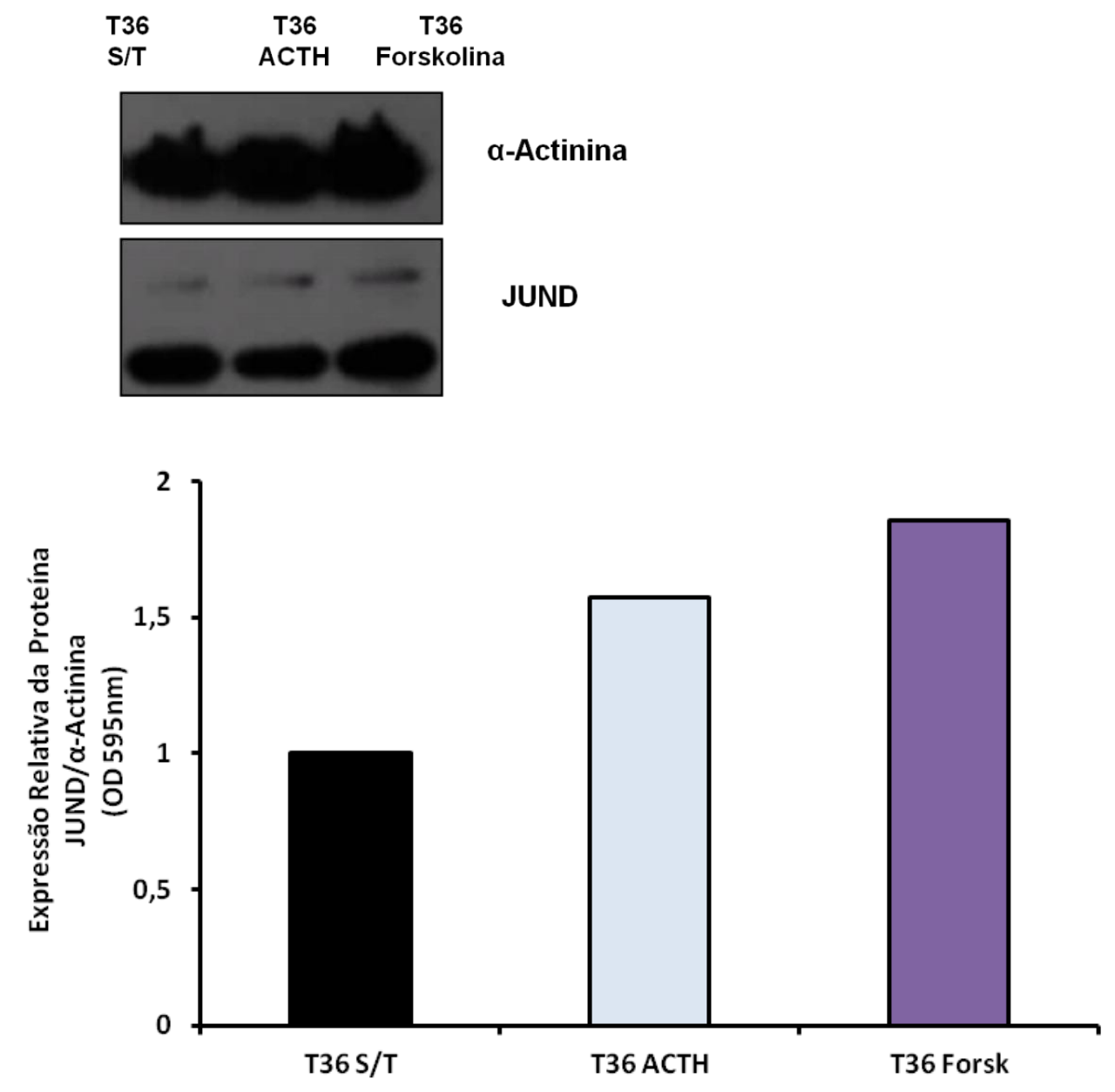

Figura 23.Expressão da proteína JUND nas células das culturas de tumores adrenocorticais tratadas com $10^{-9} \mathrm{M}$ ACTH e $10^{-7} \mathrm{M}$ Forskolina.Como controle foram utilizadas células da cultura de recidiva de carcinoma T36 sem tratamento (ST). $n=1$

A proteina FOS foi a que apresentou menor expressão basal durante crescimento exponencial das células da linhagem H295R (Figura 24) e das células T36 (Figuras 25). Devido à variação nos experimentos, o aumento obervado da expressão de Fos nas células H295R não é siginficante para nenhum dos tratamentos realizados. De fato, não foi observada expressão do gene Fos após tratamentos com ACTH e FK (Figura 17). As células T36 após tratamentos com ACTH mostram inibição dos níveis basais da proteina Fos nessas células. 

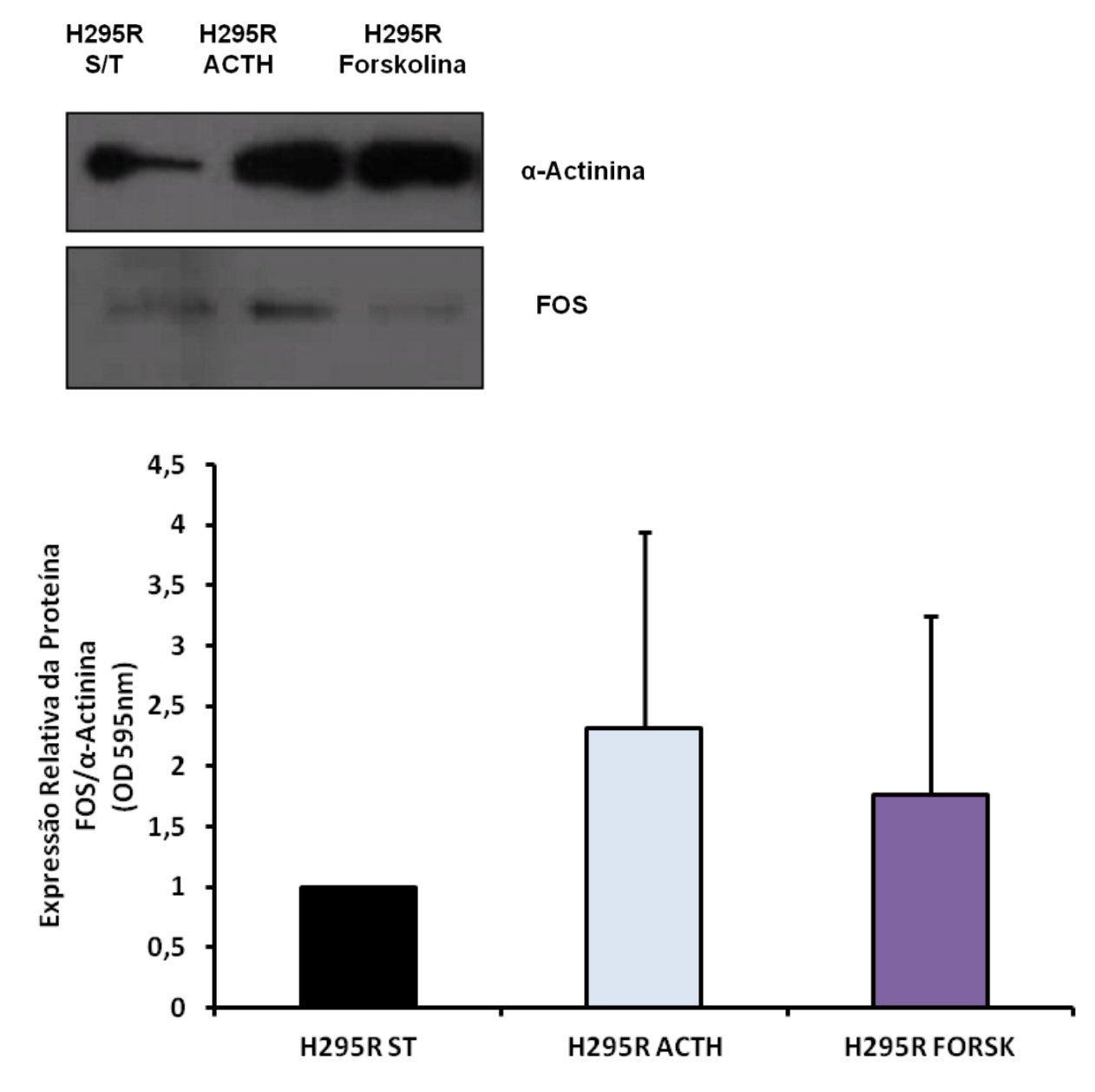

Figura 24.Expressão da proteína FOS nas células das culturas de tumores adrenocorticais tratadas com $10^{-9} \mathrm{M}$ ACTH e $10^{-7} \mathrm{M}$ Forskolina.Como controle foram utilizadas células da linhagem H295R sem tratamento (ST). Análise estatística por teste T $n=3$. 

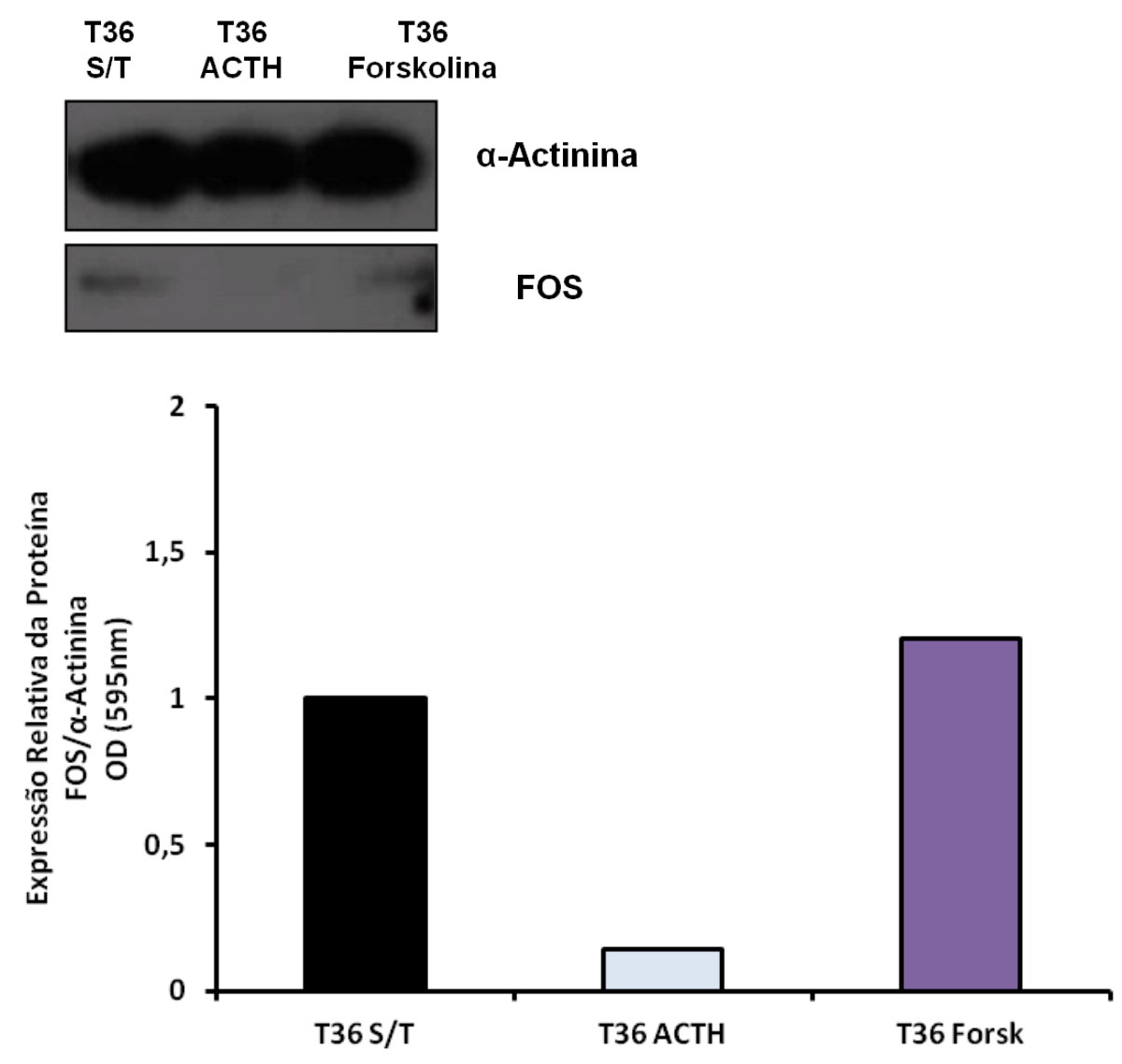

Figura 25.Expressão da proteína FOS nas células das culturas de tumores adrenocorticais tratadas com $10^{-9} \mathrm{M}$ ACTH e $10^{-7} \mathrm{M}$ Forskolina.Como controle foram utilizadas células da cultura de recidiva de carcinoma T36 sem tratamento (ST). 
5 DISCUSSÃO 
De uma maneira geral os genes da família JUN e o gene FOS estão pouco expressos em culturas de células de tumores adrenocorticais quando comparados com a adrenal normal. A baixa expressão desses genes ocorreu independente da cultura analisada, se as linhagens ou culturas de células provenientes de fragmentos de tumores. Além disso, não foi possível definir um perfil molecular de forma a distinguir culturas de células de carcinomas e adenomas, sejam de adultos ou pediátricos. A análise quantitativa da expressão desses genes corrobora o observado no experimento de PCR Array, pois nesses experimentos os genes estudados também estão pouco expressos em relação à adrenal normal. No entanto, os niveis de Jun e JunB, que foram analisados na linhagem H295R e T36 quando tratadas com ACTH e Forkolina merecem atenção. Tanto o nivel gênico quanto proteico de Jun e JunB apresentaram aumento após os tratamentos utilizados, o que lhes confere certa importância.

O envolvimento das proteinas AP-1 no câncer humano pode ocorrer em diferentes contextos da fisiologia celular como: na proliferação, que pode ser variável, isto é, pode ser na promoção ou na repressão tumoral (Shaulian \& Karin, 2001; Shaulian\& Karin, 2002); na habilidade de modular a matriz extracelular afetando a invasão e metástase (Eferl \& Wagner, 2003); na angiogênese aumentando a habilidade do tumor de lidar com as difíceis condições ambientais da falta de oxigênio (Folkman, 2004); e por último a capacidade das proteínas de AP-1 de regular a resposta inflamatória (Matthews et al., 2007), uma vez que nos últimos anos tem sido confirmada a contribuição da inflamação crônica no desenvolvimento do câncer (Agarwal, 2009).

O modelo que surgiu das observações iniciais sobre os genes de resposta primária mostrou que JUN é um regulador positivo da proliferação, cuja atividade é regulada pela quinase $\mathrm{N}$-terminal de JUN (JNK), enquanto JUNB antagoniza JUN e inibe a proliferação celular e transformação (Shaulian, 2010). Ao longo dos anos esse dogma tem sido revisto, e coletivamente esses estudos sugerem que os efeitos das proteínas Jun são extremamente contextodependente, e podem controlar negativa ou positivamente o ciclo celular, sobrevivência e transformação (Shaulian, 2010).

Depois de alguns anos sem evidências médicas sobre a habilidade de JUN ser considerado um oncogene, ele foi encontrado amplificado em um tipo 
agressivo de sarcoma, impedindo a adipogênese (Mariani et al., 2007). Além disso, JUN esteve altamente expresso na doença de Hodgkins e em um tipo de um linfoma anaplásico de pacientes, aumentando a proliferação das células no primeiro e impedindo a apoptose no segundo (Mathas et al., 2002). Por outro lado, JUN é importante para progressão do câncer de pele, mas não nas etapas iniciais (Ivanov et al., 2001). Por sua vez, em carcinomas hepatocelulares sua presença protege as células dos tumores da apoptose p53-dependente, estimulada pela ação do $\alpha$ TNF (Eferl et al., 2003).

Estudos comparativos entre fibroblastos de camundongos normais e de camundongos JUN deficientes dão suporte ao papel de JUN na proliferação celular. Esse papel parece estar relacionado com o fato de JUN antagonizar com a função anti-proliferativa de p53 (Behrens et al. 2002). E mais, a interação entre p53 e JUN aparentemente controla o desenvolvimento, regeneração e formação de tumores no fígado (Eferl et al., 2003). Apesar da identificação de JUN como um indutor de proliferação, promotor de tumor e uma oncoproteína existem evidências de sua ação prevenindo a tumorigênese, como é o caso do aumento da regulação do supressor de tumor $\mathrm{p} 14^{\mathrm{ARF}} / \mathrm{p} 19^{\mathrm{ARF}}$ (Sreeramaneni et al., 2005). Nossos resultados mostram que nas culturas de tumores adrenocorticais crescendo exponencialmente a proteina JUN está expressa, e seu nível de expressão foi aumentado após tratamento com ACTH e Forskolina, nas duas culturas estudadas. Portanto, esses resultados sugerem que tumores adrenocorticais quando responsivos ao ACTH podem alterar a expressão de JUN e com isso alterar o padrão proliferativo dos tumores. No entanto, fica ainda por esclarecer se a alteração no padrão de expressão de JUN nos tumores adrenocorticais estimula ou inibe a proliferação desses tumores. Trabalhos do nosso grupo (Baccaro et al., 2007, Torres, Lotfi, 2007), mostraram JUN como importante na resposta proliferativa do ACTH e do fator de crescimento de fibroblastos do tipo 2 (FGF2) no córtex adrenal in vivo. No entanto, JUN pode ativar o promotor do gene Dmp1, um gene que codifica uma fosfoproteina ácida que previne a formação de tumores por ativar a via Arf/p53 (Sreeramaneni et al., 2005).

O gene JUNB cuja função é de inibidor da proliferação celular (Shaulian et al., 2010), mas que cuja atividade pode contribuir para a transformação neoplásica de determinados tecidos (Shaulian et al., 2010). Foram os trabalhos 
que utilizaram animais transgênicos sem JUNB que caracterizaram essa proteína como supressora de tumor na linhagem mielóde, pois na ausência de JUNB foi observado um aumento na proliferação e uma diminuição na apoptose (Passegué et al., 2001). Além disso, a expressão de JUNB é negativamente regulada em células tronco hematopoiéticas de pacientes com leucemia miolóide crônica (Steidl et al., 2006). Os mecanismos que são utilizados por JUNB como supressor de tumor incluem a regulação negativa da ciclina $D$ bem como a positiva de p16INK4A, que por sua vez inibe as ciclinas dependentes de quinase, CDK4 e 6 (Passegué, Wagner, 2000; Bakiri et al., 2000). Juntos JUN e JUNB controlam a localização de p19 ARF, o que facilita a estabilização de p53 ( Rubbi, Milner, 2003). Portanto, para se ter uma noção se o fato desses genes estarem pouco expressos nos tumores adrenocorticais contribuem ou não para o estado tumorigênico desses tumores precisa ser ainda mais bem investigado.

Por outro lado, o envolvimento de JUND na transformação maligna é ainda menos claro. O que existe de mais substancial é sua capacidade de regular a homeostase e afetar o processo de transformação por limitar a produção de espécies reativas de oxigênio e, com isso, proteger a célula do estresse oxidativo (Zhou et al., 2007). Interessantemente, existe uma interação entre o supressor de tumor Menin, que é um produto da neoplasia endócrina múltipla do tipo I (MEN1), com JUND, de maneira que a repressão de sua atividade transcricional foi observada em tumores derivados de mutantes de Menin (Agarwal et al., 2003). Estudos desenvolvidos por Agarwal e colaboradores (2003), em ratos e fibroblastos mostrou um aumento inesperado da promoção da atividade de JUND. Foram utilizados ratos wild types e fibroblastos imortalizados $J U N D^{-/}$, e foi observada a inibição da proliferação. Com ratos missense para o gene mutante de JUND (mJunDG42E), com deficiência obrigatória para Menin, foram observados efeitos opostos, ou seja, houve uma promoção do crescimento, comprovando que quando JUND e MEN estão igualmente expressos exercem um efeito de supressor tumoral.

Existem evidências que o aumento na expressão de FOS esteja relacionado à proliferação, diferenciação e tumorigênese em tumores endometriais, que produzem de maneira anormal altos níveis de estradiol (Dubé et al., 2007). Nesses tumores o aumento de FOS está relacionado com a 
expressão dos fatores de transcrição SF-1 (steroidogenic factor 1) e LRH-1 (liver receptor homologue 1), ambos receptores nucleares importantes no processo esteroidogênico (Dubé et al., 2009). Além disso, FOS aumenta CYP11B2, enzima responsável pela produção de aldosterona na zona glomerulosa, nas células H295R (Romero et al., 2007), mas reprime CYP17, que é a enzima responsável pela produção de esteroides no córtex adrenal (Sirianni et al., 2012). Nosso resultados que mostram o aumento da expressão de FOS na linhagem H295R utilizada, está de acordo com o descrito por Romero e colaboradores na produção de aldosterona nessas células, mas não relaciona essa proteina como ativadora do ciclo celular em tumores. No entanto, resultados descritos na linhagem de tumor de camundongo, células Y1, mostraram indução de entrada em fase $S$ do ciclo celular após tratamento com ACTH (Lotfi et al., 1997).

O papel de FOS como um oncogene foi demonstrado nos estudos realizados por Milde-Langosch (2005) que descreve FOS e outros membros desta família, FOSB, Fra-1 e 2, como genes que atuam na promoção da progressão de tumores de mama. No entanto, há indícios de que em células de linhagens tumorais FOS esteja pouco expresso ou ausente, e que o aumento na expressão esteja relacionado negativamente à sobrevivência em carcinomas do epitélio ovariano (Mahner et al., 2008), de tireoide (Liu et al., 1999) e de estômago (Jin et al., 2007). Além disso, quando encontrado aumentado FOS pode induzir a apoptose em células de câncer (Healy et al., 2012). Dados de experimentos de microarray que foram depositados no National Center of Biotechnology Information's Gene Expression Omnibus por Giordano e colaboradores em 2009, ao contrário do observados nas células dos tumores adrenocorticais de adultos, mostrou que os genes JUN e FOS estão mais expressos nos tecidos de tumores adrenocorticais pediátricos. Essa baixa expressão em relação aos dados do microarray podem ocorrer devido à diferença no ambiente tumoral e as condições das células. 
6 CONCLUSÕES 
A análise do padrão de expressão de genes da família JUN e do gene FOS em culturas de células de tumores adrenais por PCR Array, mostrou que esses genes estão pouco expressos nessas culturas.

A validação da expressão gênica dos genes por PCR quantitativo confirmou os baixos níveis de expressão dos genes estudados.

Não foi possível determinar um padrão de expressão que diferenciasse os tipos de culturas celulares estudados, ou mesmo tumores adultos e pediátricos, através do estudo dos genes da família Jun e do gene Fos.

Os tratamentos com ACTH aumentam a expressão da proteina JUN e JUNB, que podem ter certa importância em tumores responsivos à esse hormônio, e que merecem ser mais bem estudados nesses tumores. 
REFERÊNCIAS 
Abiven G, Coste J, Groussin L, Anract P, Tissier F, Legmann P, Dousset B, Bertagna $X$, Bertherat J. Clinical and biological features in the; prognosis of adrenocortical cancer: poor outcome of cortisol-secreting tumors in a series of 202 consecutive patients. J Clin Endocrinol Metab. 2006; 91(7): 2650-5.

Agarwal BB Inflammation, a silent killer in cancer is not so silent! Curr Opin Pharmacol. 2009; 9(4):347-50.

Agarwal SK, Novotny EA, Crabtree JS, Weitzman JB, Yaniv M, Burns AL, Chandrasekharappa SC, Collins FS, Spiegel AM, Marx SJ Transcription factor JunD, deprived of menin, switches from growth suppressor to growth promoter Proc Natl Acad Sci. U S A, 2003; 100(19):10770-5.

Almeida MQ, Latronico AC. The molecular pathogenesis of childhood adrenocortical tumors. Horm Metab Res. 2007; 39(6):461-6.

Allolio B, Hahner S, Weismann D, Fassnacht M. Management of adrenocortical carcinoma. Clin Endocrinol (Oxf). 2004; 60(3): 273-87.

Angel P, Karin M. The role of Jun,Fos and the AP-1 complex in cell-proliferation and transformation. Elsevier Science Publishers B.V. Oct; 1991; 1072, 129-57.

Angeli S, Favretti C, Buoro S, Fandella A, Anselmo G, Conconi MT, Parnigotto PP.Effects of DHT and EGF on human hyperplastic prostate cells cultured in vitro: growth, morphology and phenotype characterisation. Ann Anat. Jun; 1997, 179(3):255-64.

Baccaro RB, Mendonça PO, Torres TE, Lotfi CF Immunohistochemical Jun/Fos protein localization and DNA synthesis in rat adrenal cortex after treatment with ACTH or FGF2. Cell Tissue Res. 2007; 328(1):7-18.

Bakiri L, Lallemand D, Bossy-Wetzel E, Yaniv M Cell cycle-dependent variations in C-Jun and JunB phosphorylation: a role in the control of cyclin D1 expression EMBO J. 2000; 19(9):2056-68.

Behrens A, Haigh J, Mechta-Grigoriou F, Nagy A, Yaniv M, Wagner, E F. Impaired intervertebral disc formation in the absence of Jun. Development. 2003; 130:103-9 The Company of Biologists Ltd doi; 10.1242/dev.00186.

Bornstein SR, Stratakis CA, Chrousos GP Adrenocortical tumors: recent advances in basic concepts and clinical management .Ann Intern Med. 1999; $130(9): 759-71$.

Bossy-Wetzel E, Bravo R, Hanahan D. Transcription factors junB and c-jun are selectively up-regulated and functionally implicated in fibrosarcoma development. Genes Dev. 1992; 6(12A):2340-51.

De acordo com:

International Committee of Medical Journal Editors. [Internet]. Uniform requirements for manuscripts submitted to Biomedical Journal: sample references. [updated $2011 \mathrm{Jul}$ 15]. Available from: http://www.icmje.org 
Bourcigaux N, Gaston V. High expression of cyclin E and G1 CDK and loss of function of p57KIP2 are involved in proliferation of malignant sporadic adrenocortical tumors. J Clin Endocrinol Metab. 2000; 85(1):322-30.

Beuschlein F, Fassnacht M, Klink A, Allolio B, Reincke M ACTH-receptor expression, regulation and role in adrenocortial tumor formation Eur $\mathrm{J}$ Endocrinol. 2001; 144(3):199-206.

Blagosklonny, M; Pardee, A The Restriction Point of the Cell Cycle. [Cell Cycle . 2002; 1:2, 103-10.

De Reyniès A, Assié G, Rickman DS, Tissier F, Groussin L, René-Corail F, Dousset B, Bertagna X, Clauser E, Bertherat J Gene expression profiling reveals a new classification of adrenocortical tumors and identifies molecular predictors of malignancy and survival J Clin Oncol. 2009; 27(7):1108-15.

Cobb MH, Goldsmith EJ. How MAP kinases are regulated. J Biol Chem. 1995 Jun 23;270(25):14843-6.

Cowan $\mathrm{KJ}^{1}$, Storey KB. Mitogen-activated protein kinases: new signaling pathways functioning in cellular responses to environmental stress. J Exp Biol. 2003 Apr;206(Pt 7):1107-15.

Dubravka, D; Scott, D. W. Regulation of the G1 phase of the mammalian cell cycle. Cell Res. 2000; 10:1-16.

Dubé C, Bergeron F, Vaillant M J, Robert NM, Brousseau C,Tremblay JJ. The nuclear receptors SF1 and LRH1 are expressed in endometrial cancer cells and regulate steroidogenic gene transcription by cooperating with AP-1 factors. Cancer Letters. 2009; 275;127-38.

Eferl R, Ricci R, Kenner L, Zenz R, David JP, Rath M, Wagner EF Liver tumor development. c-Jun antagonizes the proapoptotic activity of p53. Cell.2003; 112(2):181-92.

Eferl R, Wagner EF AP-1: a double-edged sword in tumorigenesis Nat Rev Cancer. 2003; 3(11):859-68.

Eychène $\mathrm{A}$, Rocques $\mathrm{N}$, Pouponnot $\mathrm{C} A$ new MAFia in cancer. Nat Rev Cancer. 2008; 8(9):683-93.

Fowler. T, Sen R, Roy AL. Regulation of Primary Response Genes. Published in final edited form as: Mol Cell. 2011 November 4; 44(3): 348-60. doi:10.1016/j.molcel.2011.09.014.

Folkman J Angiogenesis and c-Jun J Natl Cancer Inst. 2004; 96(9):644. 
Gao ZH, Suppola S, Liu J, Heikkilä P, Jänne J, Voutilainen R Association of $\mathrm{H} 19$ promoter methylation with the expression of $\mathrm{H} 19$ and IGF-II genes in adrenocortical tumors.J Clin Endocrinol Metab. 2002; 87(3):1170-6.

Gaujoux S, Tissier F, Groussin L, Libé R, Ragazzon B, Launay P, Audebourg A, Dousset B, Bertagna X, Bertherat J. Wnt/beta-catenin and 3',5'-cyclic adenosine 5'-monophosphate/protein kinase A signaling pathways alterations and somatic beta-catenin gene mutations in the progression of adrenocortical tumors. J Clin Endocrinol Metab. 2008; 93(10):4135-40.

Gazdar AF, Oie HK, Shackleton CH, Chen TR, Triche TJ, Myers CE, Chrousos GP, Brennan MF, Stein CA, La Rocca RV. "Establishment and characterization of a human adrenocortical carcinoma cell line that expresses multiple pathways of steroid biosynthesis." Cancer Res. 1990; 50(17): 5488-96.

Gicquel C, Le Bouc Y, Molecular markers for malignancy in adrenocortical tumors. Horm Res. 1997; 47(4-6):269-72.

Giordano TJ, Rork K, Tobias E. Molecular Classification and Prognostication of Adrenocortical Tumors by Transcriptome Profiling. Clin Cancer Res. 2009; 15:668-76.

Giordano TJ, Classification of adrenal cortical tumors: promise of the 'molecular' approach .Best Pract Res Clin Endocrinol Metab. 2010; 24(6):887-92.

Goldblum JR, ShannonR, KaldjianEP, ThinyM, Davenport $\quad$ R, Thompson $\mathrm{N}$, Lloyd RV. Immunohistochemical assessment of proliferative activity in adrenocortical neoplasms. Mod Pathol. 1993 Nov;6(6):663-8.

Hatada I, Mukai T. Genomic imprinting of $\mathrm{p} 57^{\mathrm{KIP} 2 \text {, a }}$ cyclin- dependent kinase inhibitor, in mouse. Nature Publishing Group. 1995; 11.

Hess J, Angel P, Schorpp-Kistner M. AP-1 subunits: quarrel and harmony among siblings. J Cell Sci. 2004; 117(Pt 25):5965-73.

Healy S, Protiti Khan, James R. Davie. Immediate early responde genes and cell transformation. Elsevier. 2013;137 64-77.

Herschman, H.R. Primary Response Genes Induced by Growth Factors and Tumor Promoters. Ann Rev Biochemi.1991; v.60, p.281-319.

Ilvesmäki V, Kahri Al, Miettinen PJ, Voutilainen R. Insulin-like growth factors (IGFs) and their receptors in adrenal tumors: high IGF-II expression in functional adrenocortical carcinomas. J Clin Endocrinol Metab. 1993; 77(3):8528.

Ivanov VN, Bhoumik A, Krasilnikov M, Raz R, Owen-Schaub LB, Levy D, Horvath CM, Ronai Z Cooperation between STAT3 and c-jun suppresses Fas transcription Mol Cell. 2001; 7(3):517-28.

Junqueira L.C; Carneiro J. ,Histologia Básica.10. ed. Rio de Janeiro: Guanabara Koogan. 2004. 488 p. 
Kimura E, Sonobe MH, Armelin MC, Armelin HA Induction of FOS and JUN proteins by adrenocorticotropin and phorbol ester but not by $3^{\prime}, 5^{\prime}$-cyclic adenosine monophosphate derivatives Mol Endocrinol. 1993; 7(11):1463-71.

LeHoux JG, Lefebvre A. Novel protein kinase C-epsilon inhibits human CYP11B2 gene expression through ERK1/2 signalling pathway and JunB. J Mol Endocrinol. 2006; 36(1):51-64.

Leibovitz A, McCombs WM 3rd, Johnston D, McCoy CE, Stinson JC. "New human cancer cell culture lines. I. SW-13, small-cell carcinoma of the adrenal cortex." J Natl Cancer Inst. 1973; 51(2): 691-7.

Libè R, Fratticci A, Bertherat J. Adrenocortical cancer: pathophysiology and clinical management. Endocr Relat Cancer. 2007; 14(1):13-28.

Lin SR, Lee YJ, Tsai JH Mutations of the p53 gene in human functional adrenal neoplasms.J Clin Endocrinol Metab. 1994; 78(2):483-91.

Liu J, Kahri Al, Heikkilä P, Ilvesmäki V, Voutilainen R H19 and insulin-like growth factor-II gene expression in adrenal tumors and cultured adrenal cells $\mathrm{J}$ Clin Endocrinol Metab. 1995; 80(2):492-6.

Lotfi CF, Armelin HA cfos and cjun antisense oligonucleotides block mitogenesis triggered by fibroblast growth factor-2 and ACTH in mouse Y1 adrenocortical cells J Endocrinol. 2001; 168(3):381-9.

Lotfi CF, Armelin HA c-Fos protein is a mediator in mitogenic response to ACTH Endocr Res. 1998; 24(3-4):421-4.

Lotfi CF, Todorovic Z, Armelin HA, Schimmer BP Unmasking a growthpromoting effect of the adrenocorticotropic hormone in Y1 mouse adrenocortical tumor cells J Biol Chem. 1997; 272(47):29886-91.

Luton JP, Cerdas S, Billaud L, Thomas G, Guilhaume B, Bertagna X, Laudat $\mathrm{MH}$, Louvel A, Chapuis Y, Blondeau P, et al. Clinical features of adrenocortical carcinoma, prognostic factors, and the effect of mitotane therapy. N Engl J Med. 1990; 26;322(17):1195-201.

Mariani O, Brennetot C, Coindre JM, Gruel N, Ganem C, Delattre O, Stern MH, Aurias A JUN oncogene amplification and overexpression block adipocytic differentiation in highly aggressive sarcomas Cancer Cell. 2007; 11(4):361-74.

Mathas S, Hinz M, Anagnostopoulos I, Krappmann D, Lietz A, Jundt F, Bommert K, Mechta-Grigoriou F, Stein H, Dörken B, Scheidereit C. Aberrantly expressed C-Jun and JunB are a hallmark of Hodgkin lymphoma cells, stimulate proliferation and synergize with NF-kappa B. EMBO J. 2002; 21(15):4104-13.

Matthews $\mathrm{CP}$, Colburn NH, Young MR AP-1 a target for cancer prevention Curr Cancer ;Drug Targets. 2007; 7(4):317-24. 
Mendonca BB, Lucon AM, Menezes CA, Saldanha LB, Latronico AC, Zerbini C, Madureira G, Domenice S, Albergaria MA, Camargo MH, et al. Clinical, hormonal and pathological findings in a comparative study of adrenocortical neoplasms in childhood and adulthood. J Urol. 1995;154(6):2004-9.

McNicol, A. M. The Human Adrenal Gland: Aspects of Structure, Function, and Pathology. The Adrenal Gland. V. H. T. James. New York, Raven Press. 1992;1-42.

Milde-Langosch K. The Fos family of transcription factors and their role in tumourigenesis. European Journal of Cancer. 2005; 41;2449-461.

Mukai K, Mitani F, Shimada H, Ishimura Y Involvement of an AP-1 complex in zone-specific expression of the CYP11B1 gene in the rat adrenal córtex Mol Cell Biol. 1995; 15(11):6003-12.

Mukai K, Mitani F, Agake R, Ishimura Y Adrenocorticotropic hormone stimulates CYP11B1 gene transcription through a mechanism involving AP-1 factors Eur J Biochem. 1998; 256(1):190-200.

Nateri AS, Spencer-Dene B, Behrens A. Interaction of phosphorylated C-Jun with TCF4 regulates intestinal cancer development. Nature. 2005; 437(7056):281-5.

Nishizawa M, kataoka K, Gotot N, Fujiwara K T, kawai S . V-maf, a viral oncogene that encodes a "leucine zipper" motif Proc. Nati. Acad. Sci. 1989; Vol. 86, pp. 7711-15.

Ohgaki H, Furukawa F, Takahashi M, Kleihues P. K-ras mutations are frequent in pulmonary squamous cell carcinomas but not in adenocarcinomas of WBN/Kob rats induced by $\mathrm{N}$-nitrosobis(2-oxopropyl)amine. Carcinogenesis. 1993; 14(7):1471-3.

Pardee, A.B.A restriction point for control of normal animal cell proliferation. Proc.Natl. Acad Sci. 1973; v.71,n.4,p.1286-90.

Passegué E, Jochum W, Behrens A, Ricci R, Wagner EF.JunB can substitute for Jun in mouse development and cell proliferation Nat Genet. 2002; 30(2):15866.

Passegué E, Jochum W, Schorpp-Kistner M, Möhle-Steinlein U, Wagner EF Chronic myeloid leukemia with increased granulocyte progenitors in mice lacking junB expression in the myeloid lineage Cell.2001; 104(1):21-32.

Passegué E, Wagner EF JunB suppresses cell proliferation by transcriptional activation of p16(INK4a) expression EMBO J. 2000; 19(12):2969-79.

Rassidakis GZ, Thomaides A, Atwell C, Ford R, Jones D, Claret FX, Medeiros LJ JunB expression is a common feature of CD30+ lymphomas and lymphomatoid papulosis Mod Pathol. 2005; 18(10):1365-70. 
Reincke M, Karl M, Travis WH, Mastorakos G, Allolio B, Linehan HM, Chrousos GP. p53 mutations in human adrenocortical neoplasms: immunohistochemical and molecular studies. J Clin Endocrinol Metab.1994; 78(3):790-4.

Ribeiro RC, Sandrini F, Figueiredo B, Zambetti GP, Michalkiewicz E, Lafferty AR, DeLacerda L, Rabin M, Cadwell C, Sampaio G, Cat I, Stratakis CA, Sandrini R. An inherited p53 mutation that contributes in a tissue-specific manner to pediatric adrenal cortical carcinoma. Proc Natl Acad Sci. U S A,1994; $98(16): 9330-5$.

Rincon Garriz JM, Suarez C, Capponi AM c-Fos mediates angiotensin IIinduced aldosterone production and protein synthesis in bovine adrenal glomerulosa cells. Endocrinology.2009; 150(3):1294-302.

Rubbi CP, Milner J.p53 is a chromatin accessibility factor for nucleotide excision repair of DNA damage EMBO J. 2003; 22(4):975-86.

Sancho R, Nateri AS, de Vinuesa AG, Aguilera C, Nye E, Spencer-Dene B, Behrens A. JNK signalling modulates intestinal homeostasis and tumourigenesis in mice. EMBO J. 2009; 8; 28(13):1843-54.

Seger R, Krebs EG. The MAPK signaling cascade. FASEB J. 1995 Jun;9(9):726-35.

Sidhu S, Marsh DJ, Theodosopoulos G, Philips J, Bambach CP, Campbell P, Magarey CJ, Russell CF, Schulte KM, Röher HD, Delbridge L, Robinson BG. Comparative genomic hybridization analysis of adrenocortical tumors. J Clin Endocrinol Metab. 2002; .87(7):3467-74.

Simpson ER, Waterman MR. Regulation of the synthesis of steroidogenic enzymes in adrenal cortical cells by ACTH. Annu Rev Physiol. 1988;50:427-40.

Shaulian E AP-1--The Jun proteins: Oncogenes or tumor suppressors in disguise? Cell Signal.2010;22(6):894-9.

Shaulian E, Karin M AP-1 as a regulator of cell life and death Nat Cell Biol. 2002; 4(5):E131-6.

Shaulian E, Karin M AP-1 in cell proliferation and survival Oncogene. 2001; 20(19):2390-400.

Shea-Eaton W, Sandhoff TW, Lopez D, Hales DB, McLean MP Transcriptional repression of the rat steroidogenic acute regulatory (StAR) protein gene by the AP-1 family member c-Fos. Mol Cell Endocrinol. 2002; 188(1-2):161-70.

Sherr, C.J.G1 phase progression: cycling on cue. Cell. 1994; v.79,n.4,p.551-5.

Sherr, C.J and Roberts, M.J.CDK inhibitors: positive and negative regulators of G1-Phase. Genes Dev. 1999 13: 1501-12.

Simon, D.P. Hammer, G.D . Adrenocortical stem and progenitor cells: Implications for adrenocortical carcinoma. Mol Cell Endocrinol. 2012; 351; 2-11. 
Simpson, E.M. Lauber, et al."Regulation of expression of the genes encoding steroidogenic enzymes in the ovary." J Steroid Biochem Mol Biol. 1992; 41(3-8): 409-13.

Sreeramaneni R, Chaudhry A, McMahon M, Sherr CJ, Inoue K. Ras-Raf-Arf signaling critically depends on the Dmp1 transcription factor. Mol Cell Biol. 2005; 25(1):220-32.

Steidl U, Rosenbauer F, Verhaak RG, Gu X, Ebralidze A, Otu HH, Klippel S, Steidl C, Bruns I, Costa DB, Wagner K, Aivado M, Kobbe G, Valk PJ, Passegué E, Libermann TA, Delwel R, Tenen DG. Essential role of Jun family transcription factors in PU.1 knockdown-induced leukemic stem cells Nat Genet. 2006; 38(11):1269-77.

Stojadinovic A, Brennan MF, Hoos A, Omeroglu A, Leung DH, Dudas ME, Nissan A, Cordon-Cardo C, Ghossein RA. Adrenocortical adenoma and carcinoma: histopathological and molecular comparative analysis. Mod Pathol. 2003; 16(8):742-51.

Swaroop A, Xu J, Pawar H, Jackson A, Skolnick C, Agarwal N. A conserved retina-specific gene encodes a basic motif/leucine zipper domain. Proc. Natl. Acad. Sci.1992; 89: 266-70.

Tissier F, Cavard C, Groussin L, Perlemoine K, Fumey G,; Hagneré AM, RenéCorail F, Jullian E, Gicquel C, Bertagna X, Vacher-Lavenu MC, Perret C, Bertherat J.Mutations of beta-catenin in adrenocortical tumors: activation of the Wnt signaling pathway is a frequent event in both benign and malignant adrenocortical tumors. Cancer Res. 2005; 65(17):7622-7.

Tissier F, Classification of adrenal cortical tumors: what limits for the pathological approach? Best Pract Res Clin Endocrinol Metab. 2010;24(6):87785. Review.

Torres TE, Lotfi CF Distribution of cells expressing Jun and Fos proteins and synthesizing DNA in the adrenal cortex of hypophysectomized rats: regulation by ACTH and FGF2. Cell Tissue Res. 2007; 329(3):443-55.

Weber MM, Auernhammer CJ, Kiess W, Engelhardt D Insulin-like growth factor receptors in normal and tumorous adult human adrenocortical glands Eur $\mathrm{J}$ Endocrinol. 1997; 136(3):296-303.

Weiss M, Ford VL. Differences in steroidogenesis by the subcellular fractions of adrenocortical special zone and cortex proper of the female possum (Trichosurus vulpecula). J Steroid Biochem. 1984; 21(6):701-7.

Weiss LM, Medeiros LJ, Vickery AL Jr Pathologic features of prognostic significance in adrenocortical carcinoma Am J Surg Pathol.1989; 13(3):202-6.

Wieneke JA, Thompson LD, Heffess CS. Adrenal cortical neoplasms in the pediatric population: a clinicopathologic and immunophenotypic analysis of 83 patients. Am J Surg Pathol. 2003; 27(7):867-81. 
White $\mathrm{A}^{1}$, Gibson S. ACTH precursors: biological significance and clinical relevance. Clin Endocrinol. 1998 Mar;48(3):251-5.

Zhou H, Gao J, Lu ZY, Lu L, Dai W, Xu M Role of c-Fos/JunD in protecting stress-induced cell death Cell Prolif. 2007; 40(3):431-44. 
ANEXOS 


\section{ANEXO A. Tabela de genes das placas de PCR Array}

Tabela A. 1 Genes das placas de PCR Array

\begin{tabular}{|c|c|c|c|c|}
\hline Ação & Identificador & Símbolo & Descrição & GRUPOS \\
\hline A01 & NM_005157 & $\mathrm{ABL} 1$ & $\begin{array}{l}\text { V-abl Abelson Oncogene viral } \\
\text { de leucemia murina }\end{array}$ & Fatores de transcrição \\
\hline A02 & NM_005163 & AKT1 & $\begin{array}{l}\text { Homólogo ao oncogene Viral } \\
\text { V-akt de Thimona Murino } 1\end{array}$ & Angiogênese \\
\hline A03 & NM_000038 & APC & Polipose adenomatosa coli & Adesão celular \\
\hline $\mathrm{A} 04$ & NM_000051 & ATM & $\begin{array}{l}\text { Mutado na ataxia } \\
\text { telangiectasia }\end{array}$ & Supressores de tumor / Ciclo Celular \\
\hline A05 & NM_004324 & BAX & Proteína $\mathrm{X}$ associada a BCL2 & Oncogenes / Apoptose \\
\hline A06 & NM_000633 & BCL2 & Célula-B CLL / linfoma 2 & Apoptose \\
\hline $\mathrm{A} 07$ & NM_138578 & BCL2L1 & Semelhante ao BCL-2 tipo 1 & Oncogenes / Apoptose \\
\hline A08 & NM_004327 & BCR & $\begin{array}{l}\text { Região de ponto de } \\
\text { interrupção do cluster }\end{array}$ & $\begin{array}{l}\text { Ambos Oncogenes e Supressores de } \\
\text { tumor }\end{array}$ \\
\hline A09 & NM_007294 & BRCA1 & $\begin{array}{l}\text { Câncer de mama 1, início } \\
\text { precoce }\end{array}$ & $\begin{array}{l}\text { Supressores de tumor / Fatores de } \\
\text { transcrição / Apoptose / Ciclo celular }\end{array}$ \\
\hline A10 & NM_000059 & BRCA2 & $\begin{array}{l}\text { Câncer de mama 2, início } \\
\text { precoce }\end{array}$ & $\begin{array}{l}\text { Supressores de tumor / Fatores de } \\
\text { transcrição / Transição epitélio- } \\
\text { mesenquima / Ciclo celular }\end{array}$ \\
\hline A11 & NM_001228 & CASP8 & $\begin{array}{l}\text { Caspase } 8, \text { a apoptose } \\
\text { relacionada com peptidase } \\
\text { cisteína }\end{array}$ & Oncogenes / Apoptose \\
\hline A12 & NM_053056 & CCND1 & Ciclina D1 & Ciclo celular \\
\hline B01 & NM_004360 & $\mathrm{CDH} 1$ & $\begin{array}{l}\text { Caderina 1, tipo 1, E-caderina } \\
\text { (epitelial) }\end{array}$ & Supressor de tumor / Adesão celular \\
\hline B02 & NM_000075 & CDK4 & $\begin{array}{l}\text { Ciclina dependente de quinase } \\
4\end{array}$ & Oncogenes / Ciclo Celular \\
\hline B03 & NM_000389 & CDKN1A & $\begin{array}{l}\text { Inibidor } 1 \mathrm{~A} \text { de quinase } \\
\text { dependente de ciclina ( } \mathrm{p} 21 \text {, } \\
\text { CIP1) }\end{array}$ & Ciclo Celular \\
\hline B04 & NM_000077 & CDKN2A & $\begin{array}{l}\text { Inibidor de quinase } \\
\text { dependente de ciclina 2A } \\
\text { (melanoma, p16, inhibidor } \\
\text { CDK4) }\end{array}$ & $\begin{array}{l}\text { Fatores de transcrição / Adesão } \\
\text { celular / Ciclo Celular }\end{array}$ \\
\hline
\end{tabular}




\begin{tabular}{|c|c|c|c|c|}
\hline B05 & NM_004936 & CDKN2B & $\begin{array}{l}\text { Inibidor de quinase } \\
\text { dependente de ciclina 2B } \\
\text { (p15, inibidor CDK4) }\end{array}$ & $\begin{array}{l}\text { Supressores de tumor / Transição } \\
\text { epitélio-mesenquima / Ciclo Celular }\end{array}$ \\
\hline B06 & NM_005192 & CDKN3 & $\begin{array}{l}\text { Inibidor de quinase } \\
\text { dependente de ciclina } 3\end{array}$ & Supressores de tumor / Ciclo Celular \\
\hline B07 & NM_001904 & CTNNB1 & $\begin{array}{l}\text { Catenina (caderina associada } \\
\text { a proteína) beta } 1\end{array}$ & $\begin{array}{l}\text { Fatores de transcrição / Transição } \\
\text { epitélio-mesenquima / Angiogênese / } \\
\text { Adesão celular }\end{array}$ \\
\hline B08 & NM_005225 & E2F1 & Fator de transcrição E2F1 & $\begin{array}{l}\text { Supressores de tumor / Fatores de } \\
\text { transcrição / Apoptose / Ciclo Celular }\end{array}$ \\
\hline B09 & NM_001963 & EGF & $\begin{array}{l}\text { Fator de crescimento } \\
\text { Epidermal }\end{array}$ & $\begin{array}{l}\text { Ambos Oncogenes e Supressores de } \\
\text { tumor / Angiogênese }\end{array}$ \\
\hline B10 & NM_005229 & ELK1 & $\begin{array}{l}\text { ELK1, membro da família de } \\
\text { oncogenes ETS }\end{array}$ & Oncogenes / Fatores de transcrição \\
\hline B11 & NM_004448 & ERBB2 & $\begin{array}{l}\text { Homólogo } 2 \text { ao oncogene viral } \\
\text { ( } v \text {-erb-b2) de leucemina } \\
\text { eritroblástica, oncogene } \\
\text { homólogo derivado de neuro / } \\
\text { glioblastoma (aviária) }\end{array}$ & $\begin{array}{l}\text { Ambos Oncogenes e supressores de } \\
\text { tumor / Transição epitélio- } \\
\text { mesenquima / Angiogênese }\end{array}$ \\
\hline B12 & NM_000125 & ESR1 & Receptor de Estrógeno 1 & $\begin{array}{l}\text { Ambos Oncogenes e supressores de } \\
\text { tumor / Fatores de transcrição }\end{array}$ \\
\hline C01 & NM_005238 & ETS1 & $\begin{array}{l}\text { Oncogene E26 } 1 \text { / Homólogo } \\
\text { do oncogene viral (V-ets) de } \\
\text { eitroblastose E26 }\end{array}$ & Oncogenes / Fatores de transcrição \\
\hline C02 & NM_002012 & FHIT & Gene "Fragile histidine triad" & Supressores de tumor \\
\hline C03 & NM_005252 & FOS & $\begin{array}{l}\text { Homólogo ao oncogene viral } \\
\text { ( } v \text {-fos FBJ) de osteosarcoma } \\
\text { murino }\end{array}$ & $\begin{array}{l}\text { Ambos Oncogenes e supressores de } \\
\text { tumor / Fatores de transcrição }\end{array}$ \\
\hline C04 & NM_012183 & FOXD3 & Forkhead caixa-D3 & $\begin{array}{l}\text { Supressores de tumor / Fatores de } \\
\text { transcrição }\end{array}$ \\
\hline C05 & NM_000601 & HGF & $\begin{array}{l}\text { Fator de crescimento } \\
\text { hepatocítico }\end{array}$ & $\begin{array}{l}\text { Oncogenes / Transição epitélio- } \\
\text { mesenquima / Ciclo Celular }\end{array}$ \\
\hline C06 & NM_006497 & HIC1 & Hipermetilado em câncer 1 & $\begin{array}{l}\text { Supressores de tumor / Fatores de } \\
\text { transcrição }\end{array}$ \\
\hline C07 & NM_005343 & HRAS & $\begin{array}{l}\text { Homólogo do oncogene viral } \\
\text { do sarcoma de rato v-Ha-ras } \\
\text { Harvey }\end{array}$ & $\begin{array}{l}\text { Ambos Oncogenes e supressores de } \\
\text { tumor }\end{array}$ \\
\hline C08 & NM_000876 & IGF2R & $\begin{array}{l}\text { Receptor fator de crescimento } \\
\text { semelhante à insulina } 2\end{array}$ & Supressores de tumor \\
\hline C09 & NM_004972 & JAK2 & Kinase Janus 2 & $\begin{array}{l}\text { Oncogenes / Transição epitélio- } \\
\text { mesenquima }\end{array}$ \\
\hline C10 & NM_002228 & JUN & $\begin{array}{l}\text { Oncogene homólogo ao v-jun } \\
\text { sarcoma vírus } 17 \text { / Proto- } \\
\text { oncogene JUN }\end{array}$ & $\begin{array}{l}\text { Ambos Oncogenes e supressores de } \\
\text { tumor / Fatores de transcrição }\end{array}$ \\
\hline C11 & NM_002229 & JUNB & $\begin{array}{l}\text { Oncogene homólogo ao v-jun } \\
\text { sarcoma vírus } 17 \text { B / Proto- } \\
\text { oncogene JUN B }\end{array}$ & Oncogenes / Fatores de transcrição \\
\hline
\end{tabular}




\begin{tabular}{|c|c|c|c|c|}
\hline C12 & NM_005354 & JUND & $\begin{array}{l}\text { Oncogene homólogo ao v-jun } \\
\text { sarcoma vírus } 17 \text { D / Proto- } \\
\text { oncogene JUN D }\end{array}$ & Oncogenes / Fatores de transcrição \\
\hline D01 & NM_000222 & KIT & $\begin{array}{l}\text { V-kit Hardy-Zuckerman } 4 \\
\text { homólogo de oncogene viral } \\
\text { de sarcoma felino }\end{array}$ & $\begin{array}{l}\text { Oncogenes / Transição epitélio- } \\
\text { mesenquima }\end{array}$ \\
\hline D02 & NM_003994 & KITLG & Ligante KIT & Oncogenes / Adesão celular \\
\hline D03 & NM_004985 & KRAS & $\begin{array}{l}\text { Homólogo do oncogene viral } \\
\text { do sarcoma de rato v-Ki-ras2 } \\
\text { Kirsten }\end{array}$ & $\begin{array}{l}\text { Ambos Oncogenes e supressores de } \\
\text { tumor }\end{array}$ \\
\hline D04 & NM_021960 & MCL1 & $\begin{array}{l}\text { Sequência de células de } \\
\text { leucemia mielóide } 1 \text { (BCL2- } \\
\text { relacionados) }\end{array}$ & $\begin{array}{l}\text { Oncogenes / Transição epitélio- } \\
\text { mesenquima / Apoptose }\end{array}$ \\
\hline D05 & NM_002392 & MDM2 & $\begin{array}{l}\text { MDM2 oncogene, proteína } \\
\text { ligase E3 ubiquitina }\end{array}$ & $\begin{array}{l}\text { Ambos Oncogenes e supressores de } \\
\text { tumor / Fatores de transcrição }\end{array}$ \\
\hline D06 & NM_000244 & MEN1 & $\begin{array}{l}\text { Múltiplas neoplasias } \\
\text { endócrinas } 1\end{array}$ & $\begin{array}{l}\text { Supressores de tumor / Fatores de } \\
\text { transcrição / Ciclo Celular }\end{array}$ \\
\hline D07 & NM_000245 & MET & $\begin{array}{l}\text { Proto-oncogene Met (Receptor } \\
\text { do fator de crescimento } \\
\text { hepatocítico) }\end{array}$ & Oncogenes \\
\hline D08 & NM_002412 & MGMT & $\begin{array}{l}\text { O6-metilguanina DNA } \\
\text { metiltransferase }\end{array}$ & Supressores de tumor / Apoptose \\
\hline D09 & NM_000249 & MLH1 & $\begin{array}{l}\text { Homólogo MutL } 1 \text {, câncer do } \\
\text { cólon, nonpolyposis tipo } 2\end{array}$ & Supressores de tumor \\
\hline D10 & NM_005372 & MOS & $\begin{array}{l}\text { V-mos do sarcoma murino de } \\
\text { Moloney homólogo do } \\
\text { oncogene viral }\end{array}$ & Oncogenes \\
\hline D11 & NM_005375 & MYB & Oncogene mieloblastosis vírus & Oncogenes / Fatores de transcrição \\
\hline D12 & NM_002467 & MYC & $\begin{array}{l}\text { Homólogo ao oncogene viral } \\
\text { v-myc de mielocitomatose }\end{array}$ & $\begin{array}{l}\text { Ambos Oncogenes e supressores de } \\
\text { tumor / Fatores de transcrição }\end{array}$ \\
\hline E01 & NM_005378 & MYCN & $\begin{array}{l}\text { Mielocitomatose v-myc } \\
\text { oncogene viral relacionado } \\
\text { neuroblastoma, derivado } \\
\text { (aviária) }\end{array}$ & $\begin{array}{l}\text { Ambos Oncogenes e supressores de } \\
\text { tumor / Fatores de transcrição }\end{array}$ \\
\hline E02 & NM_000267 & NF1 & Neurofibromina 1 & $\begin{array}{l}\text { Supressores de tumor / Fatores de } \\
\text { transcrição / Transição epitélio- } \\
\text { mesenquima / Angiogênese / Adesão } \\
\text { celular }\end{array}$ \\
\hline E03 & NM_000268 & NF2 & Neurofibromina 2 & $\begin{array}{l}\text { Supressores de tumor / Adesão } \\
\text { celular }\end{array}$ \\
\hline E04 & NM_003998 & NFKB1 & $\begin{array}{l}\text { Fator nuclear do gene } \\
\text { enhancer do polipeptídeo leve } \\
\text { Kappa nas células-B } 1\end{array}$ & $\begin{array}{l}\text { Ambos Oncogenes e supressores de } \\
\text { tumor / Fatores de transcrição }\end{array}$ \\
\hline E05 & NM_020529 & NFKBIA & $\begin{array}{l}\text { Inibidor de fator nuclear do } \\
\text { gene enhancer do } \\
\text { polipeptídeo leve Kappa nas } \\
\text { células-B 1, Alfa } \\
\end{array}$ & Oncogenes \\
\hline E06 & NM_002524 & NRAS & $\begin{array}{l}\text { Oncogene homólogo de } \\
\text { neuroblastoma RAS viral (v- } \\
\text { ras) }\end{array}$ & Oncogenes \\
\hline
\end{tabular}




\begin{tabular}{|c|c|c|c|c|}
\hline E07 & NM_002645 & PIK3C2A & $\begin{array}{l}\text { Fosfatidilinositol-4-fosfato de } \\
\text { 3-cinase, catalítica da } \\
\text { subunidade do tipo } 2 \text { alfa }\end{array}$ & $\begin{array}{l}\text { Ambos Oncogenes e supressores de } \\
\text { tumor }\end{array}$ \\
\hline E08 & NM_006218 & PIK3CA & $\begin{array}{l}\text { Fosfatidilinositol-4 ,5-bifosfato- } \\
\text { 3-quinase, subunidade } \\
\text { catalítica alfa }\end{array}$ & Oncogenes \\
\hline E09 & NM_033238 & PML & Leucemia promielocítica & $\begin{array}{l}\text { Oncogenes / Fatores de transcrição / } \\
\text { Angiogênese }\end{array}$ \\
\hline E10 & NM_002737 & PRKCA & Proteina quinase $\mathrm{C}$, Alfa & Oncogenes \\
\hline E11 & NM_002880 & RAF1 & $\begin{array}{l}\text { Oncogene homólogo v-raf-1 } \\
\text { leucemia viral } 1\end{array}$ & Oncogenes \\
\hline E12 & NM_000964 & RARA & Receptor ácido retinóico, Alfa & Oncogenes / Fatores de transcrição \\
\hline F01 & NM_007182 & RASSF1 & $\begin{array}{l}\text { Família Ras associação } \\
\text { domínio (RalGDS/AF-6), } \\
\text { membro } 1\end{array}$ & Supressores de tumor \\
\hline F02 & NM_000321 & RB1 & Retinoblastoma 1 & $\begin{array}{l}\text { Ambos Oncogenes e supressores de } \\
\text { tumor / Fatores de transcrição }\end{array}$ \\
\hline F03 & NM_002908 & REL & $\begin{array}{l}\text { Oncogene homólogo viral v-rel } \\
\text { reticuloendoteliose viral } \\
\text { (Aviário) }\end{array}$ & Oncogenes / Fatores de transcrição \\
\hline F04 & NM_020630 & RET & Proto-oncogene Ret & $\begin{array}{l}\text { Ambos Oncogenes e supressores de } \\
\text { tumor / Fatores de transcrição }\end{array}$ \\
\hline F05 & NM_002944 & ROS1 & $\begin{array}{l}\text { C-ros oncogene } 1 \text {, receptor } \\
\text { tyrosina quinase }\end{array}$ & Oncogenes \\
\hline F06 & NM_001754 & RUNX1 & $\begin{array}{l}\text { Factor de transcrição } 1 \\
\text { relacionado com Runt }\end{array}$ & $\begin{array}{l}\text { Oncogenes / Fatores de transcrição / } \\
\text { Angiogênese }\end{array}$ \\
\hline F07 & NM_004350 & RUNX3 & $\begin{array}{l}\text { Factor de transcrição } 3 \\
\text { relacionado com Runt } 3\end{array}$ & $\begin{array}{l}\text { Supressores de tumor / Fatores de } \\
\text { transcrição / Transição epitélio- } \\
\text { mesenquima }\end{array}$ \\
\hline F08 & NM_002961 & S100A4 & $\begin{array}{l}\text { Cálcio S100 ligado a proteína } \\
\text { A4 }\end{array}$ & $\begin{array}{l}\text { Supressores de tumor / Transição } \\
\text { epitélio-mesenquima }\end{array}$ \\
\hline F09 & NM_002639 & SERPINB5 & $\begin{array}{l}\text { Inibidor de serpina peptidase, } \\
\text { subtipo B, membro } 5\end{array}$ & Supressores de tumor \\
\hline $\mathrm{F} 10$ & NM_014631 & SH3PXD2A & SH3 e PX domínios $2 \mathrm{~A}$ & $\begin{array}{l}\text { Ambos Oncogenes e supressores de } \\
\text { tumor }\end{array}$ \\
\hline $\mathrm{F} 11$ & NM_005359 & SMAD4 & Membro 4 da família SMAD & $\begin{array}{l}\text { Supressores de tumor / Fatores de } \\
\text { transcrição / Transição epitélio- } \\
\text { mesenquima }\end{array}$ \\
\hline $\mathrm{F} 12$ & NM_005417 & $\mathrm{SRC}$ & $\begin{array}{l}\text { Oncogene homólogo viral v- } \\
\text { src (Schmidt-Ruppin A-2) }\end{array}$ & Oncogenes \\
\hline G01 & NM_003150 & STAT3 & $\begin{array}{l}\text { Transdutor de sinal e ativação } \\
\text { de transcrição } 3\end{array}$ & Oncogenes / Fatores de transcrição \\
\hline G02 & NM_000455 & STK11 & Serina/treonina quinase 11 & Supressores de tumor / Ciclo Celular \\
\hline
\end{tabular}




\begin{tabular}{|c|c|c|c|c|}
\hline G03 & NM_000660 & TGFB1 & $\begin{array}{l}\text { Fator transformador de } \\
\text { crescimento, beta } 1\end{array}$ & $\begin{array}{l}\text { Ambos Oncogenes e supressores de } \\
\text { tumor / Fatores de transcrição / } \\
\text { Transição epitélio-mesenquima / } \\
\text { Angiogênese / Adesão Celular }\end{array}$ \\
\hline G04 & NM_000594 & TNF & Fator de necrose tumoral & $\begin{array}{l}\text { Ambos Oncogenes e supressores de } \\
\text { tumor / Fatores de transcrição / } \\
\text { Apoptose }\end{array}$ \\
\hline G05 & NM_000546 & TP53 & Proteína p53 & $\begin{array}{l}\text { Ambos Oncogenes e supressores de } \\
\text { tumor / Fatores de transcrição / Ciclo } \\
\text { Celular }\end{array}$ \\
\hline G06 & NM_005427 & TP73 & Proteína p73 & $\begin{array}{l}\text { Supressores de tumor / Fatores de } \\
\text { transcrição }\end{array}$ \\
\hline G07 & NM_000368 & TSC1 & Esclerose tuberosa 1 & $\begin{array}{l}\text { Supressores de tumor / Fatores de } \\
\text { transcrição }\end{array}$ \\
\hline G08 & NM_000551 & VHL & $\begin{array}{l}\text { Supressor de tumor Von } \\
\text { Hippel-Lindau }\end{array}$ & $\begin{array}{l}\text { Supressores de tumor / Fatores de } \\
\text { transcrição / Transição epitélio- } \\
\text { mesenquima / Apoptose }\end{array}$ \\
\hline G09 & NM_000378 & WT1 & Tumor Wilms 1 & $\begin{array}{l}\text { Supressores de tumor / Fatores de } \\
\text { transcrição }\end{array}$ \\
\hline G10 & NM_016373 & WWOX & $\begin{array}{l}\text { WW domínio contendo } \\
\text { óxidoredutase }\end{array}$ & Supressores de tumor \\
\hline G11 & NM_006297 & $\mathrm{XRCC} 1$ & $\begin{array}{l}\text { X-ray reparação } \\
\text { complementando com defeito } \\
\text { de reparo em células de } \\
\text { hamster chinês } 1\end{array}$ & Supressores de tumor \\
\hline G12 & NM_014943 & $\mathrm{ZHX} 2$ & Zinc fingers e homeoboxes 2 & Oncogenes / Fatores de transcrição \\
\hline $\mathrm{H} 01$ & NM_004048 & B2M & Microblobulina 2 Beta & Genes de Referência \\
\hline $\mathrm{H} 02$ & NM_000194 & HPRT1 & Hipoxantina fosforribosil 1 & Genes de Referência \\
\hline $\mathrm{H} 03$ & NM_012423 & RPL13A & Proteína Ribossomal L13a & Genes de Referência \\
\hline $\mathrm{H} 04$ & NM_002046 & GAPDH & $\begin{array}{l}\text { Gliceraldeído 3-fosfato } \\
\text { desidrogenase }\end{array}$ & Genes de Referência \\
\hline $\mathrm{H} 05$ & NM_001101 & ACTB & Beta Actina & Genes de Referência \\
\hline $\mathrm{H} 06$ & SA_00105 & HGDC & $\begin{array}{l}\text { Human Genomic DNA } \\
\text { Contamination }\end{array}$ & Genes de Referência \\
\hline $\mathrm{H} 07$ & SA_00104 & RTC & $\begin{array}{l}\text { Controle de Transcrição } \\
\text { Reversa }\end{array}$ & Controles da placa \\
\hline $\mathrm{H} 08$ & SA_00104 & RTC & $\begin{array}{l}\text { Controle de Transcrição } \\
\text { Reversa }\end{array}$ & Controles da placa \\
\hline $\mathrm{H} 09$ & SA_00104 & RTC & $\begin{array}{l}\text { Controle de Transcrição } \\
\text { Reversa }\end{array}$ & Controles da placa \\
\hline
\end{tabular}


Anexos/77

\begin{tabular}{|l|l|l|l|l|} 
H10 & SA_00103 & PPC & Controle positivo de PCR & Controles da placa \\
\hline H11 & SA_00103 & PPC & Controle positivo de PCR & Controles da placa \\
\hline H12 & SA_00103 & PPC & Controle positivo de PCR & Controles da placa \\
\hline
\end{tabular}

